\title{
Macroeconomic Effects of Entrepreneurship from an International Perspective
}

\author{
Renata Dana Nițu-Antonie ${ }^{1, *}$, Emóke-Szidónia Feder ${ }^{1}$ and Valentin Partenie Munteanu ${ }^{2}$ \\ 1 Marketing and International Economic Relations Department, Faculty of Economics and Business \\ Administration, West University of Timișoara, Timișoara 300223, Romania; emoke.feder@e-uvt.ro \\ 2 Management Department, Faculty of Economics and Business Administration, West University of Timișoara, \\ Timișoara 300223, Romania; valentin.munteanu@e-uvt.ro \\ * Correspondence: renata.nitu@e-uvt.ro; Tel.: +40-256-592-571
}

Received: 26 May 2017; Accepted: 25 June 2017; Published: 3 July 2017

\begin{abstract}
At the panel level, formed of 33 European economies based on resource efficiency enhancers or innovation-driven factors, the present study followed causal relationships between the conditions of economic efficiency ensuring framework and different macroeconomic effects of entrepreneurship, mediated by the entrepreneurial behavior, with delays up to five years. Research findings highlighted that a national efficiency enhancing framework acts as stimulant for the entrepreneurial behavior of nascent entrepreneurs and new small and medium-sized business owners, while a superior level of entrepreneurial behavior generates simultaneous and/or medium-term favorable effects on the growth of gross domestic product, exports, imports and employment, therefore assuring, besides immediate growth, sustainable economic and social progress in the analyzed countries. The causal relationships identified are consistent with the results of other empirical studies in the field.
\end{abstract}

Keywords: framework of economic efficiency enhancers; entrepreneurial intentions; entrepreneurial activity; entrepreneurial aspirations; sustainable macroeconomic effects of entrepreneurship

\section{Introduction}

Within the present context of globalization, entrepreneurship is perceived as one of the economic growth engines at European level in the 2020 perspective. Following the adoption of the Small Business Act in 2008, through which the European Union outlined an initial strategic agenda to boost entrepreneurial energies, the Europe 2020 Strategy revived the emphasis on entrepreneurship as a key factor of economic growth, social progress and employment. Within this framework, identifying the macroeconomic effects of entrepreneurship in the case of the European countries is an ongoing research theme, with academic interest and managerial impact for the small- and medium-sized firms and for the development of start-ups. Answering the question regarding the existence of simultaneous and/or time-lagged direct effects of entrepreneurial behavior on economic growth, inward-outward international trade and the number of employed people across Europe is the main objective of the present research. Based on the Global Entrepreneurship Monitor (GEM) [1,2] entrepreneurial process model, the current research took into account the entrepreneurial behavior of individuals within the business start-up and management phases, in the case of the European Union member states and aspiring countries with efficiency and innovation-driven economies [3], being the only ones that can ensure the conditions of a proper entrepreneurial framework development [2]. The theoretical aspects placed at the foundation of the research model elaboration assure its originality and differentiates it from a replicative model. The enhancement of the GEM entrepreneurial process model by considering the internal and international market oriented entrepreneurial behavior and the expansion of the empirical research from a static to a dynamic approach of multiple macroeconomic effects of the entrepreneurial behavior are the novel elements of the undertaken research. The proposed model can 
also be used in further empirical deductive type research aiming to test the entrepreneurship theory within an extended European, international or global context.

Definitions of entrepreneurship commonly share the idea of creating profitable activities as a result of opportunity identification, exploration and exploitation [4].

The profit-generating opportunities that guide the actions of entrepreneurs may source from the imbalances manifested on the market. The origin of entrepreneurial profits is endogenous to the market, as a consequence of identifying and exploiting pre-existent market imbalances or engaging in new opportunities generated by the own entrepreneurial dynamics.

Entrepreneurs identify the possibility of mutually beneficial exchange transactions on the market due to the existence of productivity gains, which were not exploited as the result of labor division and specialization of bidders. They recognize possibilities of enhanced use of different production factors compared to other entrepreneurs and entrants extant on the market, by improving time and scarce resource allocation, thus modifying the cost function. Under the conditions of an imperfect market, the supply-demand balance is shifted over time, as a result of scattered information and limited rationality of exchange participants. Price imbalances, given by different perceived values and prices for the same good, are the main source of profit opportunities for entrepreneurs [5-7], materializing in new business ideas and markets.

The origin of profit opportunities offered by the market can also be sought in the innovative action of entrepreneurs. The Schumpeterian theory argues that the origin of innovation profits is exogenous to the market, being a result of the entrepreneur's creative cognitive actions, whereas the exploitation of innovation outcomes destroys other entrepreneurs' profit opportunities [7]. Within the Schumpeterian vision, innovation is synonymous with creating new sources of competitive advantage on the market, thus substituting the existent ones, by improving and/or renewing fabrication techniques and products, generating in fact a creative destruction of entrepreneurial opportunities. The entrepreneur does not discover a profit opportunity on the market, but rather creates it, as a result of an entrepreneurial intention to orient resources towards innovation, and the obtained results will replace old production and consumption routines.

The economic changes that entrepreneurs inadvertently induce, as a result of their activities, generate new profit opportunities, which are more easily identified if they are integrated into social networks $[7,8]$. The collective process of detecting these opportunities allows the creation of mental models at the level of entrepreneurs [9]. These reduce the information ambiguity provided by the market, determining the identification and exploitation of opportunities independently of the entrepreneurs' individual preferences, depending on the perception and understanding favored by the network of externalities. Consequently, an enhancement of the engaging effect appears, followed by an increase in the number entrepreneurs and/or entrepreneurial firms, explaining the dynamics of competitive intensity at sectoral economic activity level.

New entrepreneurial firms, emerged as response to extant knowledge not completely exploited by companies already present on the market [10], lead to a reconciliation of visions regarding the manner in which an entrepreneur identifies and creates profit opportunities. In this case, profit opportunities are not entirely exogenous because they are created through investments in knowledge spillovers resulting from other companies' innovation, nor are entirely endogenous being dependent on the current state and future development trends of markets. Depending on their characteristics, firms can provide resource combinations leading either to a gradual internationalization in successive phases or to a rapid internationalization from the moment of their emergence on the market [11]. Entrepreneurs identify on the domestic or foreign markets a mutually beneficial exchange, by stimulating future demand, and accordingly profit opportunities are created, identified and exploited. Once the opportunities are identified, their exploitation presume a cognitive perception and risk assessment process [12] comprehended by the entrepreneur in order to create a new firm or new activities within existing firms [13], with direct impact on economic and social plans within developed and emerging countries [14-17]. 
The paper has been structured in four parts, as follows: a literature review on empirical macroeconomic approaches as entrepreneurial effects; elaboration of research hypotheses to be tested, of the conceptual research model and its operationalization through constructs; presentation of the research methodology and the results obtained from the statistical analysis of the data; and identification of conclusions that can be drawn from the comprehended research, emphasizing as well the boundaries and potential future research directions.

\section{Literature and Research Hypotheses}

Entrepreneurship involves the concurrent existence of market opportunities generating entrepreneurial events and entrepreneurs as change agents.

Entrepreneurial events, materialized in the creation of new economic activities, are the result of the complementarities between the opportunity perception process of entrepreneurs and the type of action they undertook in order to exploit these opportunities.

Entrepreneurs, as cognitive individuals, ensure the shift from perception to action as a consequence of their ability to recognize opportunities based on the information they seek, identify and decode on the basis of previously acquired knowledge through learning [18], and depending on their aspirations. The skills that generate entrepreneurial spirit and aspirations exist to a greater or lesser extent in every individual and manifests whenever simulative conditions emerge. Identifying opportunities requires their assessment [12], depending on the availability of necessary resources to create new activities [19]. New economic activities materialize in either the creation of new firms or new economic activities within existing firms [13]. This act of creation is of entrepreneurial type, if it determines the entry of a firm into different newly identified markets or the entry with new products and services on existing markets [20], a choice depending on the entrepreneur's orientation towards growth and/or innovation [21,22]. Once the entrepreneurial act has been completed, smalland medium-sized entrepreneurial firms can develop their static and dynamic capabilities based on entrepreneurial, market, learning, and innovation orientations, while the ambidextrous approach enhance the performance, competitiveness, viability and sustainability of the entrepreneurial firms [23] acting in different business environments. Entrepreneurial activity does not manifest in a temporal and spatial vacuum, being affected by the context in which entrepreneurs act. The entrepreneurial process takes place within a set of general and specific economic and social conditions of the entrepreneurial environment $[1,24]$. The conditions of the entrepreneurial framework reflect the potential of a country to foster the manifestation of entrepreneurship [24] and represent a mechanism that encourage entrepreneurial spirit and expectations [25], imposing the identification of its impact on the entrepreneurial behavior. Consequently, the following research hypothesis was established:

Hypothesis 1 (H1): A superior level of the conditions of the economic efficiency framework (higher education and continuous training, goods market efficiency, labor market efficiency, financial market development and sophistication, technological readiness, and market size) hasa positive influence on the entrepreneurial behavior.

Business opportunities for small- and medium-sized firms are mainly determined by business environment dynamics or instability, as a result of consumer and competitor behavior, and the international economic context. The entrepreneur's orientation toward these new opportunities pursues the rapid growth of the small- and medium-sized businesses. As a result of firms domestic and international market orientation, the anticipation and exploitation of business opportunities requires the consideration of environmental threats [26], with the goal to assure continuously a superior value for customers [27] and to achieve a high level of performance for the firm [28]. In the case of young entrepreneurial firms, the link between the opportunities identified by the entrepreneurs and the uncertainty of the business environment is moderated by their knowledge gained through individual and intuitive experiential learning, determining the decision of pursuing an internationalization in gradual or rapid stages from the moment of their market appearance [11]. 
The Global Entrepreneurship Monitor [2] highlighted the direct relationship between the level of economic development of a country and the level and type of entrepreneurial activity in order to provide the necessary data for a global and overall assessment of the role of entrepreneurship on the economic growth of various countries. Popescu et al. [29] advocate that the sustainable development of any market economy lies in the enhancement of the private sector via value creating entrepreneurial new firms and demand improvements. Complementary, Hosseininia and Ramezani [30] argued multiple potential favorable effects of entrepreneurship at ecological, social and economic levels, when adopting a sustainable approach. Therefore, the aggregated value created by domestic and international entrepreneurial ventures can be estimated at national level as component of gross domestic product and exports, while the higher employment rate transforms into increased level and quality of internal demand, satisfied with a higher volume of domestic and imported products.

Using the operationalization of GEM [2] for entrepreneurship, several theoretical and empirical studies have found positive effects of entrepreneurial activity on the economic growth in developed OECD countries [31,32]. Valliere and Peterson [33] concluded that entrepreneurial activity, highlighted by the creation of new firms, is a predictor of GDP growth in developed countries with certain time-lags. For these countries [34] and at regional level [17,35], the positive impact of entrepreneurship on economic growth is empirically confirmed, and furthermore enhanced by the export orientation, at both firm [36] and aggregated national level. Li et al. [37,38] argue that further empirical research on the relationship between entrepreneurship and growth is needed, especially in the context of emerging economies.

Hypothesis 2 (H2): A higher level of entrepreneurial behavior manifestation generates a higher level of economic development.

Hypothesis 3 (H3): A higher level of the entrepreneurial behavior manifestation generates an increase of imports.

Hypothesis 4 (H4): A higher level of the entrepreneurial behavior manifestation generates the amplification of exports.

The complex nature of entrepreneurship suggests an ambiguity about its impact on job creation [29]. At the level of the different countries, studies highlighted both the positive impact of the creation of new firms on employment [39-41], and the negative influence too [16]. This lack of clarity can be attributed, on the one hand, to a counterbalance between the creation of new jobs within the new firms and the destruction of similar ones within the existing organizations [42]. Self-employment associated with the necessity entrepreneurship intensifies in recession times and diminishes during economic revival [43-45], producing negative effects on the survival of new firms and on economic growth [32]. The dynamic relationship between employment rate and market entry of firms may suggest a time-delayed structure. There are some examples of analysis on increasing employment rates using time-lagged variables [46], however the majority of research studies either do not use these gaps or consider very short time periods [47-49]. Consequently, the continuation of research on the immediate and time-lagged effects of entrepreneurial behavior on the labor market required the formulation of the next hypothesis:

Hypothesis 5 (H5): A higher level of the entrepreneurial behavior manifestation generates an enlargement of the employed population.

Following the determination of the research hypotheses, we proceeded with the conceptual model elaboration, data collection and statistical investigation of the existence or non-existence of the causal relations between the constituting constructs. 


\section{Conceptual Model}

The proposed research model (Figure 1) has been created to study the macroeconomic effects generated by entrepreneurial behaviors in an international context. Causal relations have been investigated between the conditions of economic efficiency ensuring framework and entrepreneurial behavior, and between the entrepreneurial behavior and the level of economic development, the internationalization degree of the small- and medium-sized entrepreneurial firms, and the increase of employed population in the case of European countries, considered with a time gap up to five years to assess more sustainable positive effects in time.

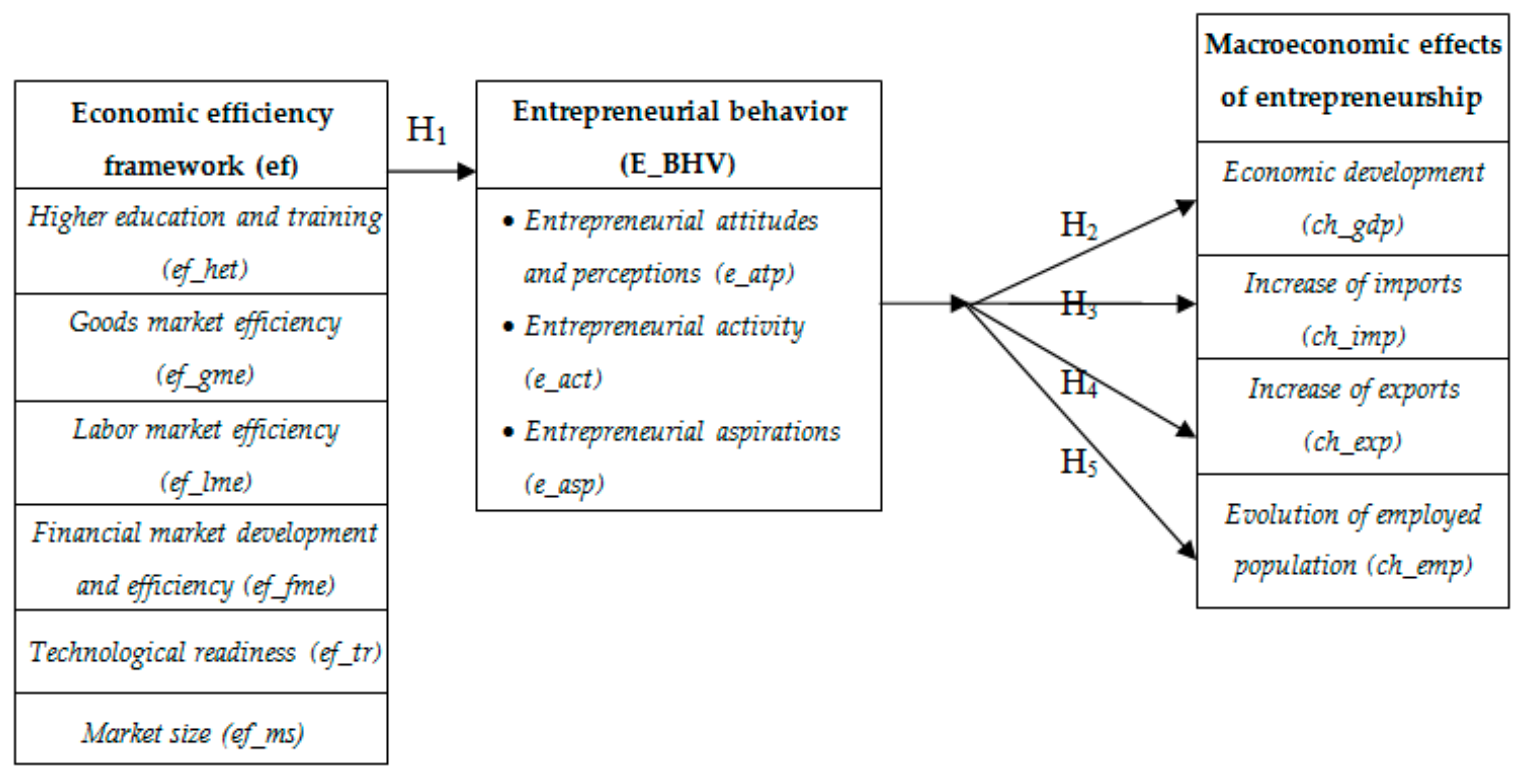

Figure 1. Conceptual model of the entrepreneurial process.

The proposed model regarding the entrepreneurial process is an extension of the Global Entrepreneurship Monitor (GEM) model [1,2,24]. Starting from some design specific principles of the reference model (GEM), the developed conceptual model of the entrepreneurial process only considered the entrepreneurial behavior of individuals in the moment of starting and running a business. The conditions of the economic efficiency framework influence the entrepreneurial behavior that generates macroeconomic effects on the level of economic development, international affairs and the growth of the employed population in the European area. The originality of the research model is generated by the expansion of the scope of the macroeconomic effects of entrepreneurship and their study from a longitudinal time lagged perspective.

The operational clarity of the constructs included in the research model facilitates the empirical evaluation process of the relationships between them to validate, reject or modify the model.

The construct based operationalization of the model implied the use of several pillar indicators specific to the GEM operationalization. Constructs and dimensions of the operational model become latent variables, measured via directly quantifiable variables, as follows:

- The economic efficiency framework measures various aspects of the conditions and characteristics specific to the secondary and tertiary economic activity sectors that stimulate, sustain or hinder the entrepreneurial process. According to the World Economic Forum (2008) [50], the directly measurable and quantifiable variables refer to the: level of university education and training, level of goods market efficiency, level of labor market efficiency, the degree of financial market development and sophistication, level of technological readiness, and market size (Table 1), specific for the natural, social and economic components of the national business environment. 
Table 1. Operationalization of economic efficiency ensuring framework construct.

\begin{tabular}{cl}
\hline \multicolumn{1}{c}{ Construct } & \multicolumn{1}{c}{ Variables } \\
\hline & - Level of university education and training \\
& - Level of goods market efficiency \\
Economic efficiency framework & - Level of labor market efficiency \\
& - Degree of financial market development and sophistication \\
- Level of technological readiness & - Market size \\
\hline
\end{tabular}

- The entrepreneurial behavior construct measures the dynamics of the entrepreneurial phenomenon at national level, considering people in the situation of starting a new business or managing a small- and medium-sized firms. According to the GEM Consortium [2,51], the dimensions and variables that build-up and operationalize this construct are:

- $\quad$ The level of entrepreneurial attitudes involved eight variables: entrepreneurial intention rate, entrepreneurship as desirable career choice rate, fear of failure rate, media attention for entrepreneurship, high status successful entrepreneurship, know start-up entrepreneur rate, rate of perceived capabilities, and rate of perceived opportunities.

- The level of entrepreneurial activities is composed of six variables: nascent entrepreneurship rate, new business ownership rate, total early-stage entrepreneurial activity, established business ownership rate, improvement-driven opportunity entrepreneurial activity, and necessity-driven entrepreneurial activity.

- $\quad$ The level of entrepreneurial aspirations is formed by three variables: the relative rate of growth expectation early-stage entrepreneurial activity, rate of new product early-stage entrepreneurial activity, and the rate of international orientation early-stage entrepreneurial activity (Table 2).

Table 2. Operationalization of the entrepreneurial behavior construct.

\begin{tabular}{|c|c|c|}
\hline Construct & Dimensions & Variables \\
\hline \multirow{3}{*}{$\begin{array}{l}\text { Entrepreneurial } \\
\text { behavior }\end{array}$} & - $\quad$ Entrepreneurial attitudes & $\begin{array}{l}\text { - } \quad \text { Entrepreneurial intention } \\
\text { - } \quad \text { Perceived capabilities } \\
\text { - } \quad \text { Perceived opportunities } \\
\text { - } \quad \text { Entrepreneurship as desirable career choice } \\
\text { - } \quad \text { Fear of failure rate } \\
\text { - } \quad \text { Media attention for entrepreneurship } \\
\text { - } \quad \text { High status successful entrepreneurship } \\
\text { - } \quad \text { Know start-up entrepreneur rate }\end{array}$ \\
\hline & - $\quad$ Entrepreneurial activity & $\begin{array}{ll}\text { - } & \text { Nascent entrepreneurship rate } \\
\text { - } & \text { New business ownership rate } \\
\text { - } & \text { Total early-stage entrepreneurial activity } \\
\text { - } & \text { Established business ownership rate } \\
\text { - } & \text { Improvement-driven opportunity } \\
& \text { entrepreneurial activity } \\
\text { - } & \text { Necessity-driven entrepreneurial activity }\end{array}$ \\
\hline & - $\quad$ Entrepreneurial aspirations & $\begin{array}{l}\text { - } \quad \text { Growth expectation early-stage entrepreneurial activity } \\
\text { - } \quad \text { New product early-stage entrepreneurial activity } \\
\text { - } \quad \begin{array}{l}\text { International orientation early-stage } \\
\text { entrepreneurial activity }\end{array}\end{array}$ \\
\hline
\end{tabular}


- The construct regarding the macroeconomic effects of entrepreneurship measures the impact of entrepreneurial behavior on foreign trade, economic development and labor market in a country (Table 3). The dimensions and indicators that operationally build this construct are:

- $\quad$ economic growth measured by the gross domestic product growth rate;

- $\quad$ increase of imports measured by the variable change in volume of imports of goods and services;

- $\quad$ increase of exports measured by the variable change in volume of exports of goods and services; and

- evolution of the employed population measured by the variable growth of employment rate.

Table 3. Operationalization of the construct macroeconomic effects of entrepreneurship.

\begin{tabular}{lllll}
\hline \multicolumn{1}{c}{ Construct } & & \multicolumn{1}{c}{ Dimensions } & & \multicolumn{1}{c}{ Variables } \\
\hline Macroeconomic & - & Economic development & - & Change rate of GDP \\
effects of & - & Increase of imports & - & Change in volume of imports of goods and services \\
entrepreneurship & - & Increase of exports & - & Change in volume of exports of goods and services \\
& - & Evolution of employed population & - & Change in employment rate \\
\hline
\end{tabular}

The original GEM model [2] proposed the analysis of multiple macroeconomic effects of the entrepreneurial behavior. The growth rates of exports and imports were sourced from the World Economic Outlook database [52], created by the International Monetary Fund, to measure the macroeconomic effect of the international entrepreneurship process on the foreign trade of a country. Similarly, gross domestic product growth is queried from the World Economic Outlook database [52] to analyze the gross added value created by the entrepreneurial firms. The increase in the population's employment rate has been proposed to measure the influence of the entrepreneurial mindset on the labor market through the newly created jobs, data being selected from the Key Indicators of the Labour Market database [53] of the International Labour Organization.

\section{Data Analysis, Empirical Results and Discussion}

In the case of the current research, data regarding the value of operational variables and dimensions have been obtained from secondary data sources (Table 4). Within the current study, the sustainability of national growth from economic and social perspective considers the positive evolution for several macroeconomic indicators, indispensable for the initiation of a favorable change process, as well as maintaining it in time for the durable development of the countries.

Table 4. Source of collected data.

\begin{tabular}{|c|c|}
\hline Constructs & Data Source \\
\hline $\begin{array}{l}\text { Economic efficiency ensuring } \\
\text { framework }\end{array}$ & World Economic Forum-Global Competitiveness Report [50] \\
\hline Entrepreneurial behavior & $\begin{array}{l}\text { GEM Consortium-Global Entrepreneurship Monitor: global and national } \\
\text { reports [51] }\end{array}$ \\
\hline $\begin{array}{l}\text { Gross domestic product (GDP); } \\
\text { International openness of a country } \\
\text { toward exports and imports; } \\
\text { Employment rate }\end{array}$ & $\begin{array}{l}\text { International Monetary Fund-World Economic Outlook Database [52]; } \\
\text { International Monetary Fund-World Economic Outlook Database [52]; } \\
\text { International Labour Organization-Key Indicators of the Labour Market } \\
\text { Database [53] }\end{array}$ \\
\hline
\end{tabular}

The data used in the statistical analysis refers to the 2006-2015 timeframe, and, to highlight the potential sustainable effects created over time, the national macroeconomic effects consider the 
2007-2016, 2008-2017, 2009-2018, 2010-2019, and 2011-2020 intervals, depending on the analyzed time gap. Data from the above indicated secondary sources were generated based on national and regional statistical research conducted by various organizations, through sample surveys with standard questionnaires applied to different samples of respondents (adults, entrepreneurs or managers of small- and medium-sized firms, and experts).

The analyzed panel encompass European countries, selected depending on their development level, according to the World Economic Forum (2016) [3,51], including those based on resource efficiency (Bosnia and Herzegovina, Croatia, Greece, Hungary, Latvia, Lithuania, Poland, Romania, Macedonia, Russia, Serbia, Slovakia, and Turkey) and the innovation-driven ones (Austria, Belgium, Czech Republic, Denmark, Estonia, Finland, France, Germany, Iceland, Ireland, Italy, Luxembourg, the Netherlands, Norway, Portugal, Slovenia, Spain, Switzerland, and United Kingdom). For the 33 surveyed countries, the data panel is unbalanced, due to the lack and interruption of annual data within the 10-year time span (2006-2015) necessary to operationalize the entrepreneurial behavior. The EU, as an attempt to create an economic union in Europe, can be characterized by a significant level of economic, social and legal integration via the common institutions, laws, treaties, arrangements and policies, creating far more similarities than differences within the panel and the regional business environment. Therefore, the considered EU member states and aspiring countries from the European panel serves as a central and relevant context to conduct the research and test the hypotheses at aggregated panel level. The main objective of the statistical data analysis represents the evaluation of the research model hypotheses, the assumptions regarding the existence or non-existence of causal relations between the constructs at aggregated panel level and to make comparisons on the impact of entrepreneurship in the European context and in time. For the statistical analysis of secondary data, STATA 13 software was used to model, estimate and assess the simultaneous and medium-term sustainable time-lagged effects generated by the European entrepreneurship.

Modeling the complex structural equations (SEM) with multiple observed and latent variables is considered a well performing and powerful technique in multivariate data analysis [54]. Simultaneous regressions were created to estimate the equation system reflecting the mathematical description of the research model: $Y_{i t}=\alpha+\beta_{i t} * X_{i t}+\tau_{i t} * \mu_{i t}+\varepsilon_{i t}$, where $Y=$ endogenous dependent variable (increase in gross domestic product, in import, in export, and in employment rate), $\mathrm{X}=$ exogenous independent variables (conditions of economic efficiency framework: university education and training, goods market efficiency, labor market efficiency, financial market development and efficiency, technological readiness, market size, entrepreneurial activity, entrepreneurial aspirations, entrepreneurial attitude and perceptions), $\mu=$ endogenous latent variable (entrepreneurial behavior), $\alpha=$ constant, $\beta$ and $\tau=$ coefficients (corresponding to path analysis), $\varepsilon=$ the error term for observed and latent variables, $\mathrm{i}=1, \ldots, \mathrm{N}$ (number of countries in the panel), and $\mathrm{t}=1, \ldots, \mathrm{T}$ (number of years analyzed in the time series). For the construction and estimation of the empirical model, specifications were introduced in the SEM Builder, and due to the limitation imposed by few unavailable data, the Maximum Probability with Missing Values (MLMV) econometric method was applied. MLMV is the most commonly preferred option with several advantages [54], considered adequate for the present research due to the limited number and spread of missing values, and their random distribution across the country panel and time-series, permitting data integrity and the elimination of biased or poor results, although for all the empirical models imposed the relaxation of the multivariate normality. When multivariate normality cannot be assured, the only alternative is the asymptotic distribution free (ADF) method, having as main shortfalls the list-wise deletion of missing data, abridged sample size and limited performance [54]. Finally, the SEM analysis was completed with the evaluation of the Overall Goodness-of-fit indices.

The empirical analysis applying SEM aims three main objectives: building the entrepreneurial behavior as a latent construct based on the dimensions provided in the reference model; assessing the impact of specific components of the economic efficiency framework on stimulating entrepreneurial behavior; and analyzing the simultaneous and time-lagged effects of entrepreneurial behavior on the 
growth of gross domestic product (Model 1), of imports (Model 2), of exports (Model 3) and of the employment rate (Model 4).

For the four models regarding the simultaneous effects over time, analysis of the log-likelihood derived data of the observed matrix (IOM) reveals a series of statistically significant relationships (Table 5).

In the case of modeling the direct and indirect influences on the economic growth measured via gross domestic product (Model 1), the obtained results indicate: a positive, direct and significant relationship ( $p \approx 0.05, \beta=0.806$ ) between the goods market efficiency, as condition of the economic efficiency framework (ef_gme), and entrepreneurial behavior (E_BHV); a positive, direct and significant relationship ( $p=0.043<0.05, \beta=0.457$ ) between the degree of financial market development and sophistication, as another condition of the economic efficiency framework (ef_fme), and entrepreneurial behavior (E_BHV); a negative, direct and significant relationship $(p=0.000<0.05, \beta=-0.670)$ between the market size, as further condition of the economic efficiency framework (ef_ms), and entrepreneurial behavior (E_BHV); positive, direct and significant relationships $\left(p=0.000<0.05, \beta_{\mathrm{e} \_ \text {act }}=1\right.$ * constrained, $\left.\beta_{\mathrm{e} \_a s p}=2.497, \beta_{\mathrm{e} \_a t p}=2.921\right)$ between entrepreneurial activity $\left(\mathrm{e} \_\right.$act $)$, entrepreneurial aspiration (e_asp), entrepreneurial attitude and perceptions (e_atp) and the latent variable of entrepreneurial behavior (E_BHV); and positive and significant relationship $(p=0.009<0.05, \tau=0.998)$ between entrepreneurial behavior (E_BHV) and dependent variable economic growth (ch_gdp). In the above context, hypothesis $\mathrm{H} 1$ is partially valid and hypothesis $\mathrm{H} 2$ is valid.

Table 5. Simultaneous influences and goodness-of-fit indices for the SEM of the research model using the MLMV estimation method without delay.

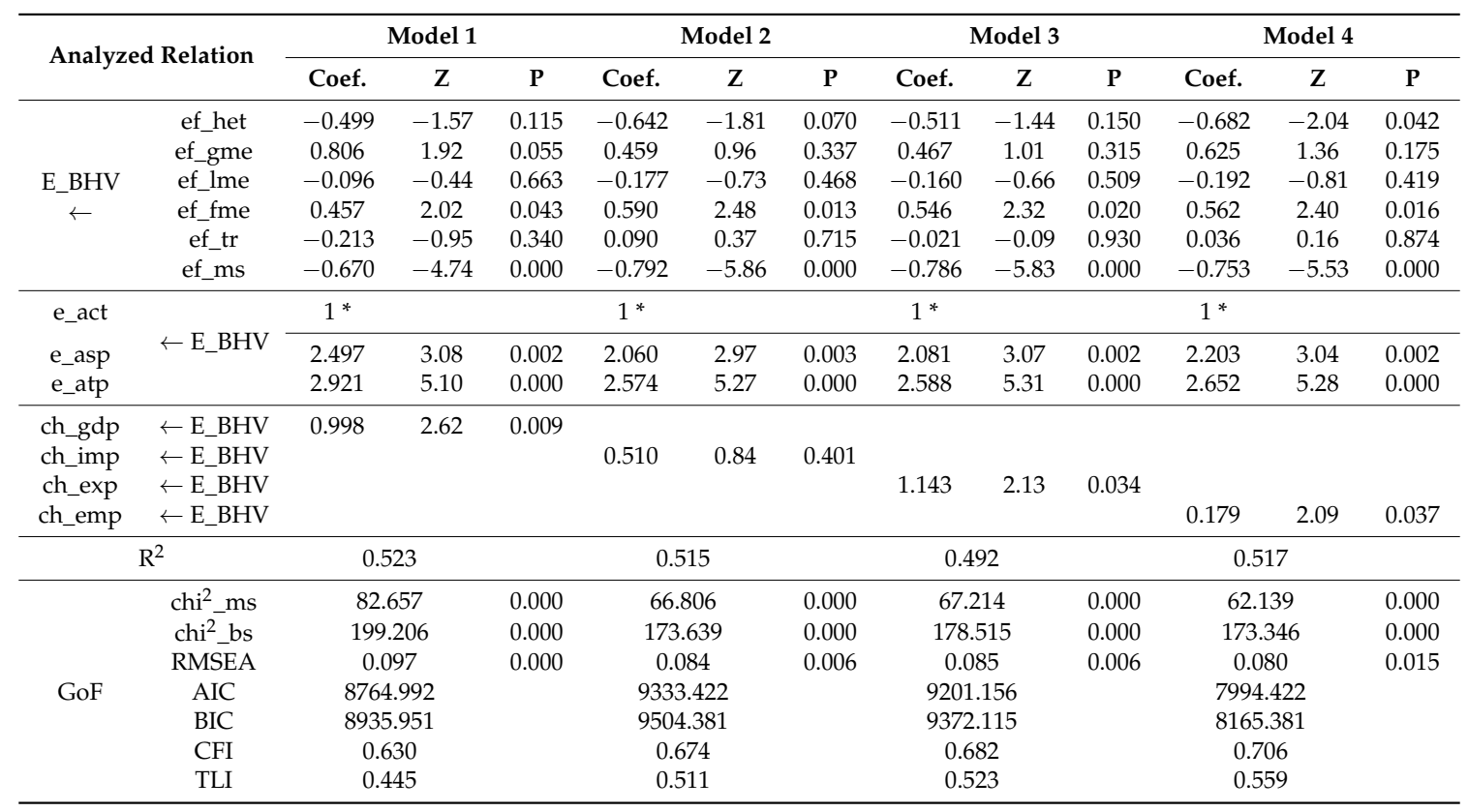

Note: Coef. $=$ path estimate coefficient; $\mathrm{Z}=$ critical ratio; $\mathrm{P}=$ significance level; ${ }^{*}=$ constrained; $\mathrm{GoF}=$ Goodness-of-fit.

Modeling the direct and indirect simultaneous effects on the increase of imports of goods and services (Model 2) highlighted: a positive, direct and significant relationship $(p=0.013<0.05$, $\beta=0.590$ ) between the financial market development and sophistication, as condition of the economic efficiency framework (ef_fme), and entrepreneurial behavior (E_BHV); a negative, direct and significant relationship ( $p=0.000<0.05, \beta=-0.792)$ between market size, as element of the economic efficiency framework (ef_ms), and entrepreneurial behavior (E_BHV); and positive, direct and significant relationships $\left(\mathrm{p}_{\mathrm{e} \_ \text {asp }}=0.003, \mathrm{p}_{\mathrm{e} \_ \text {atp }}=0.000<0.05, \beta_{\mathrm{e} \_ \text {act }}=1{ }^{*}\right.$ constrained, $\beta_{\mathrm{e} \_ \text {asp }}=2.06, \beta_{\mathrm{e} \_ \text {atp }}=2.574$ ) between entrepreneurial activity (e_act), entrepreneurial aspirations (e_asp), entrepreneurial attitude 
and perceptions (e_atp) and entrepreneurial behavior as a latent variable (E_BHV). Consequently, hypothesis $\mathrm{H} 1$ is partially valid, while hypothesis $\mathrm{H} 3$ is not valid. See Figure 2.

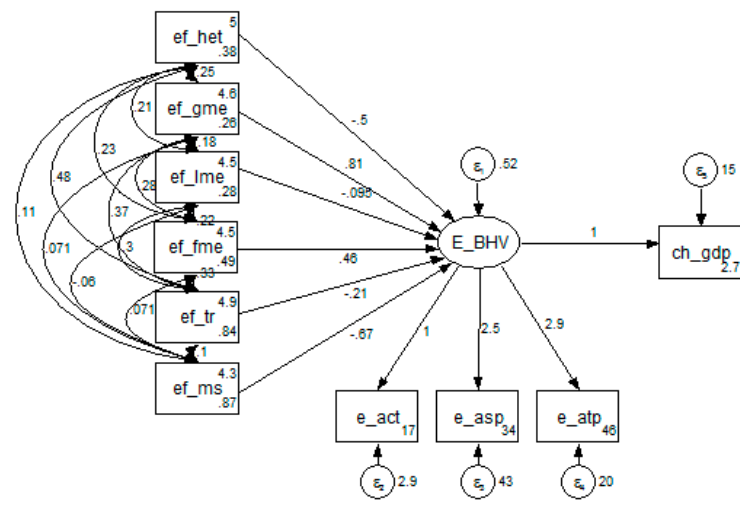

(a)

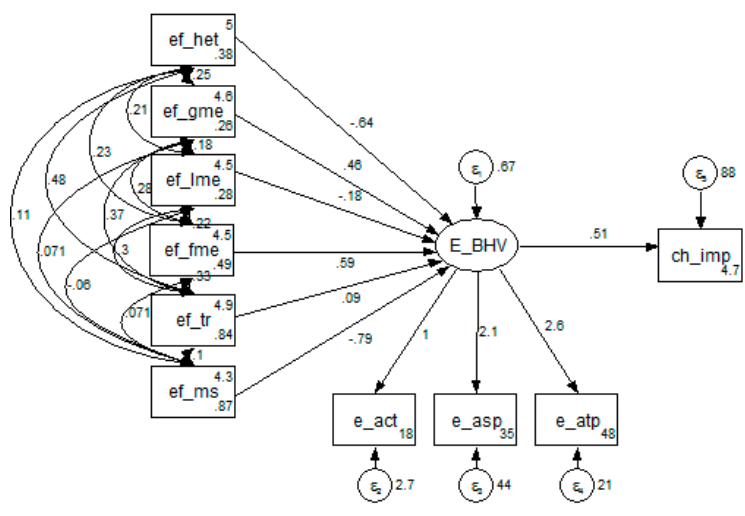

(b)

Figure 2. Structural equation models in the case of economic growth and imports, as potential effects of entrepreneurship: (a) economic growth; and (b) growth of imports.

Regarding direct and indirect influences model on the growth of exports of goods and services (Model 3), the results indicate: a positive, direct and significant relationship $(p=0.02<0.05, \beta=0.546)$ between the degree of financial market efficiency and sophistication, as circumstance of the economic efficiency framework (ef_fme), and entrepreneurial behavior (E_BHV); a negative, direct and significant relationship ( $p=0.000<0.05, \beta=-0.786$ ) between the market size, as condition of the economic efficiency framework (ef_ms), and entrepreneurial behavior (E_BHV); positive, direct and significant relationships ( $\mathrm{p}_{\mathrm{e} \_a s p}=0.002, \mathrm{p}_{\mathrm{e} \_ \text {atp }}=0.000<0.05, \beta_{\mathrm{e} \_a c t}=1{ }^{*}$ constrained, $\beta_{\mathrm{e} \_a s p}=2.081, \beta_{\mathrm{e} \_a t p}=2.588$ ) between entrepreneurial activity (e_act), entrepreneurial aspiration (e_asp), entrepreneurial attitude and perceptions (e_atp) and entrepreneurial behavior as a latent variable (E_BHV); and positive and significant relationship ( $p=0.034<0.05 \tau=1.143$ ) between entrepreneurial behavior (E_BHV) and increase of exports, as dependent variable (ch_exp). The obtained results lead to the partial validation of hypothesis $\mathrm{H} 1$ and to the validation of hypothesis $\mathrm{H} 4$.

The empirical modeling of total effects on the growth of employed population (Model 4 ) emphasize the existence of: a negative, direct and statistically significant relationship $(p=0.042<0.05$, $\beta=-0.682$ ) between higher education and continuous training, as condition of the efficiency-driven framework (ef_het), and entrepreneurial behavior (E_BHV); a positive, direct and significant relation $(p=0.016<0.05, \beta=0.562)$ between the financial market development and sophistication, as component of the economic efficiency framework (ef_fme), and the entrepreneurial behavior (E_BHV); a negative, direct and significant relationship ( $p=0.000<0.05, \beta=-0.753)$ between the market size, as element of the economic efficiency framework (ef_ms), and entrepreneurial behavior (E_BHV); positive, direct and significant relationships ( $\mathrm{p}_{\mathrm{e} \_ \text {asp }}=0.002, \mathrm{p}_{\mathrm{e} \_ \text {atp }}=0.000<0.05, \beta_{\mathrm{e} \_ \text {act }}=1 *$ constrained, $\left.\beta_{\mathrm{e} \_a s p}=2.203, \beta_{\mathrm{e} \_a t p}=2.652\right)$ between entrepreneurial activity $\left(\mathrm{e} \_\right.$act $)$, entrepreneurial aspiration (e_asp), entrepreneurial attitude and perceptions (e_atp) and entrepreneurial behavior as a latent variable (E_BHV); and positive and significant relationship $(p=0.037<0.05 \tau=0.179)$ between entrepreneurial behavior (E_BHV) and the growth of employed population, as dependent variable (ch_emp). Therefore, hypothesis H5 is valid, while hypothesis H1 is just partially valid. See Figure 3.

Goodness-of-fit indices have been considered to evaluate the proposed research model, as compared to the saturated model, in which all the variables are correlated, and to the basic model, which assumes the total lack of correlations between the variables. In this sense, $\mathrm{chi}^{2}$ is in normal limits, having $p<0.05$ in the case of all the four specified models depending on the effect variables. The values of Root mean squared error of approximation (RMSEA) also fall within the normal limits, with probabilities reaching the upper limit in the case of analyzing imports and exports. Similarly, 
Comparative Fit Index (CFI) tends to reach the 0.8 limit, while the Tucker-Lewis Index (TLI) records lower values than those indicated as reasonable thresholds in the statistical literature.

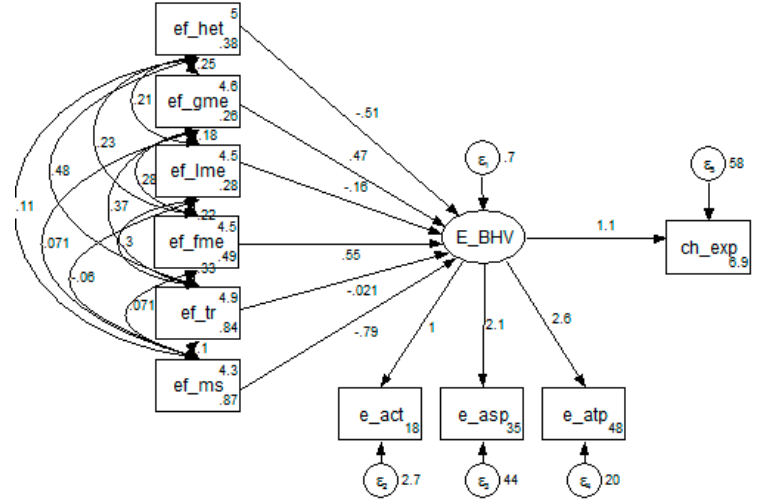

(c)

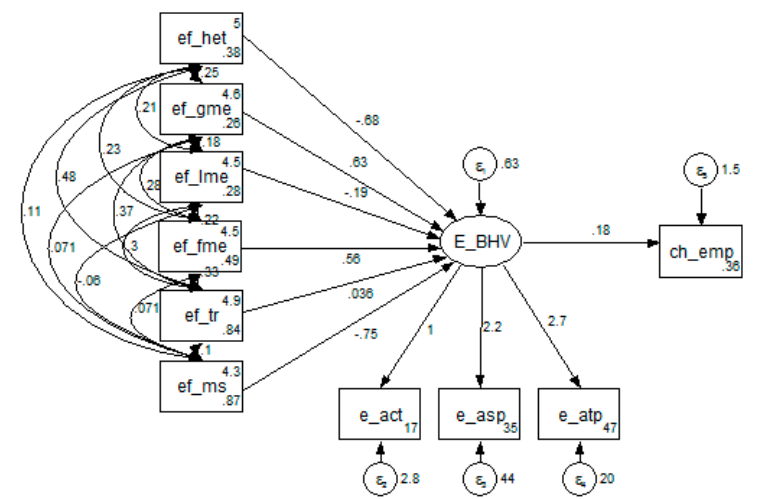

(d)

Figure 3. Structural equation models in the case of export and employment rate growth, as potential effects of entrepreneurship: (c) growth in exports; and (d) increase of employment rate.

The short-term effects of the research model, especially with one-year (Table A1 in Appendix A) and two-year (Table A2 in Appendix A) lags, demonstrate no statistically significant results of entrepreneurial activity on the four macroeconomic indicators in the case of the selected countries.

For models with three-year delayed effects, data analysis validates some statistically significant relationships between the components of economic efficiency framework and entrepreneurial behavior and the manifested behavior on exports (Table 6).

Table 6. SEM results for the research model with MLMV estimation method and three-year delay.

\begin{tabular}{|c|c|c|c|c|c|c|c|c|c|c|c|c|c|}
\hline \multirow{2}{*}{\multicolumn{2}{|c|}{ Analyzed Relations }} & \multicolumn{3}{|c|}{ Model 1} & \multicolumn{3}{|c|}{ Model 2} & \multicolumn{3}{|c|}{ Model 3} & \multicolumn{3}{|c|}{ Model 4} \\
\hline & & Coef. & $\mathrm{Z}$ & $\mathbf{P}$ & Coef. & $\mathbf{Z}$ & $\mathbf{P}$ & Coef. & $\mathbf{Z}$ & $\mathbf{P}$ & Coef. & $\mathbf{Z}$ & $\mathbf{P}$ \\
\hline \multirow{6}{*}{$\begin{array}{c}\text { E_BHV } \\
\leftarrow\end{array}$} & ef_het & -0.911 & -2.56 & 0.010 & -0.814 & -2.35 & 0.019 & -0.889 & -2.70 & 0.007 & -0.331 & -0.85 & 0.398 \\
\hline & ef_gme & 0.587 & 1.15 & 0.248 & 0.477 & 0.98 & 0.326 & 0.496 & 1.07 & 0.283 & 0.309 & 0.72 & 0.471 \\
\hline & ef_lme & -0.161 & -0.67 & 0.504 & -0.183 & -0.76 & 0.448 & -0.157 & -0.68 & 0.499 & -0.199 & -0.84 & 0.399 \\
\hline & ef_fme & 0.446 & 1.57 & 0.116 & 0.534 & 2.10 & 0.035 & 0.498 & 2.02 & 0.044 & 0.693 & 3.19 & 0.001 \\
\hline & ef_tr & 0.312 & 1.29 & 0.195 & 0.259 & 1.10 & 0.273 & 0.259 & 1.18 & 0.238 & -0.108 & -0.42 & 0.676 \\
\hline & ef_ms & -0.808 & -5.95 & 0.000 & -0.818 & -6.12 & 0.000 & -0.809 & -6.04 & 0.000 & -0.691 & -4.28 & 0.000 \\
\hline e_act & & $1 *$ & & & $1 *$ & & & $1 *$ & & & $1 *$ & & \\
\hline e_asp & $\leftarrow$ E_BHV & 2.422 & 2.78 & 0.005 & 2.296 & 2.88 & 0.004 & 2.444 & 3.01 & 0.003 & 1.677 & 2.69 & 0.007 \\
\hline e_atp & & 2.416 & 5.10 & 0.000 & 2.469 & 5.19 & 0.000 & 2.505 & 5.14 & 0.000 & 2.910 & 4.76 & 0.000 \\
\hline ch_gdp & $\leftarrow$ E_BHV & 0.395 & 1.49 & 0.137 & & & & & & & & & \\
\hline ch_imp & $\leftarrow$ E_BHV & & & & 0.715 & 1.23 & 0.217 & & & & & & \\
\hline ch_exp & $\leftarrow$ E_BHV & & & & & & & 1.077 & 2.17 & 0.030 & & & \\
\hline ch_emp & $\leftarrow$ E_BHV & & & & & & & & & & -0.186 & -1.73 & 0.083 \\
\hline
\end{tabular}

Note: Coef. = path estimate coefficient; $\mathrm{Z}=$ critical ratio; $\mathrm{P}=$ significance level; ${ }^{*}=$ constrain.

In the case of modeling direct and indirect influences with three-year delay on economic growth (Model 1), the following paths were identified: a direct and statistically significant negative relationship ( $p=0.01<0.05, \beta=-0.911)$ between higher education and continuous training (ef_het) and entrepreneurial behavior (E_BHV); a negative, direct and significant relationship $(p=0.000<0.05$, $\beta=-0.808$ ) between the market size (ef_ms) and entrepreneurial behavior (E_BHV); and positive, direct and significant relationships ( $\mathrm{p}_{\mathrm{e} \_ \text {asp }}=0.005, \mathrm{p}_{\mathrm{e} \_ \text {atp }}=0.000<0.05, \beta_{\mathrm{e} \_ \text {act }}=1{ }^{*}$ constrained, $\left.\beta_{\mathrm{e} \_a s p}=2.422, \beta_{\mathrm{e} \_ \text {atp }}=2.416\right)$ between entrepreneurial activity $\left(\mathrm{e} \_\right.$act $)$, entrepreneurial aspiration (e_asp), entrepreneurial attitude and perceptions (e_atp) and entrepreneurial behavior as latent variable (E_BHV). Therefore, in this context of three-year delay, hypothesis H1 is partially valid, while hypothesis $\mathrm{H} 2$ is invalid. 
Concerning the modeled effects on the increase of imports of goods and services (Model 2) obtained over a delay of three years, the following assumptions are valid: the direct and significant negative relationship $(p=0.019<0.05, \beta=-0.814)$ between higher education and continuous training (ef_het) and entrepreneurial behavior (E_BHV); a positive, direct and significant relationship ( $p=0.035<0.05, \beta=0.534$ ) between the financial market development and efficiency (ef_fme) and the entrepreneurial behavior (E_BHV; direct and significant negative relationship $(p=0.000<0.05$, $\beta=-0.818$ ) between market size (ef_ms) and entrepreneurial behavior (E_BHV); and positive, direct and significant relationships ( $\mathrm{p}_{\mathrm{e} \_ \text {asp }}=0.003, \mathrm{p}_{\mathrm{e} \_ \text {atp }}=0.000<0.05, \beta_{\mathrm{e}_{\_} \text {act }}=1{ }^{*}$ constrained, $\left.\beta_{\mathrm{e} \_a s p}=2.296, \beta_{\mathrm{e} \_a t p}=2.469\right)$ between entrepreneurial activity $\left(\mathrm{e} \_\right.$act$)$, entrepreneurial aspiration (e_asp), entrepreneurial attitude and perceptions (e_atp) and latent variable entrepreneurial behavior (E_BHV). Consequently, hypothesis $\mathrm{H} 1$ is partially valid and hypothesis $\mathrm{H} 3$ is not valid.

Modeling the three-year delayed total influences on the growth of exports in goods and services (Model 3), the results prove: direct and statistically significant negative relationship $(p=0.00<0.05$, $\beta=-0.889$ ) between higher education and continuing education (ef_het) and entrepreneurial behavior (E_BHV); a positive, direct and significant relationship $(p=0.044<0.05, \beta=0.498)$ between the financial market development and sophistication (ef_fme) and entrepreneurial behavior (E_BHV); a direct and significant negative relationship $(p=0.000<0.05, \beta=-0.809)$ between market size (ef_ms) and entrepreneurial behavior (E_BHV); positive, direct and significant relationships ( $p_{\mathrm{e} \_a s p}=0.004$, $\mathrm{p}_{\mathrm{e} \_a t p}=0.000<0.05, \beta_{\mathrm{e} \_a c t}=1 *$ constrained, $\left.\beta_{\mathrm{e} \_a s p}=2.444, \beta_{\mathrm{e} \_a t p}=2.505\right)$ between entrepreneurial activity (e_act), entrepreneurial aspiration (e_asp), entrepreneurial attitude and perceptions (e_atp) and entrepreneurial behavior as latent variable (E_BHV); and a positive and significant relationship $(p=0.03<0.05, \tau=1.077)$ between the entrepreneurial behavior (E_BHV) and increase in exports (ch_exp). The findings lead to the partial validation of hypothesis H1 and to the validation of hypothesis $\mathrm{H} 4$.

Regarding the three-year lagged effects on the growth of employed population (Model 4), empirical results probe: a positive, direct and significant relationship $(p=0.001<0.05, \beta=0.693)$ between the development and sophistication of the financial market (ef_fme) and entrepreneurial behavior (E_BHV); a direct and significant negative relationship $(p=0.000<0.05, \beta=-0.691)$ between market size (ef_ms) and entrepreneurial behavior (E_BHV); and positive, direct and significant relationships $\left(\mathrm{p}_{\mathrm{e} \_a s p}=0.007, \mathrm{p}_{\mathrm{e} \_a t p}=0.000<0.05, \beta_{\mathrm{e} \_a c t}=1^{*}\right.$ constrained, $\left.\beta_{\mathrm{e} \_a s p}=1.677, \beta_{\mathrm{e} \_a t p}=2.9150\right)$ between entrepreneurial activity (e_act), entrepreneurial aspiration (e_asp), entrepreneurial attitude and perceptions (e_atp) and entrepreneurial behavior as latent variable (E_BHV). Hence, hypothesis $\mathrm{H} 1$ is partially valid and hypothesis $\mathrm{H} 5$ is refuted.

With respect to the four-year time lag models, data analysis supports several statistically significant relationships for some conditions of the economic efficiency framework and entrepreneurial behavior, together with their impact on economic growth rate, imports and exports (Table 7).

In the case of the modeling four-year shifted direct and indirect influences on economic growth (Model 1), the following relations are relevant: a direct and significant negative relation $(p=0.001<0.05$, $\beta=-0.899$ ) between higher education and training (ef_het) and entrepreneurial behavior (E_BHV); a positive, direct and significant relationship $(p=0.001<0.05, \beta=1.271)$ between the products and goods market efficiency (ef_gme) and entrepreneurial behavior (E_BHV); a direct and significant negative relationship $(p=0.000<0.05, \beta=-0.644)$ between market size (ef_ms) and entrepreneurial behavior (E_BHV); positive, direct and significant relationships ( $\mathrm{p}_{\mathrm{e} \_a s p}=0.004, \mathrm{p}_{\mathrm{e} \_ \text {atp }}=0.000<0.05, \beta_{\mathrm{e} \_ \text {act }}=1$ * constrained, $\beta_{\mathrm{e} \_ \text {asp }}=4.060, \beta_{\mathrm{e} \_ \text {atp }}=2.522$ ) between entrepreneurial activity ( $\mathrm{e} \_$act $)$, entrepreneurial aspiration (e_asp), entrepreneurial attitude and perceptions (e_atp) and entrepreneurial behavior latent variable (E_BHV); and a positive and significant relationship $(p=0.036<0.05, \tau=0.729)$ between the entrepreneurial behavior (E_BHV) and raise of domestic value added in the form of economic growth (ch_gdp). Based on the obtained results, hypothesis H1 is partially valid and hypothesis H2is valid.

Regarding the total effects on the growth of imports of goods and services (Model 2) with a four-year delay, the following results are pertinent: a direct and significant negative relationship 
$(p=0.023<0.05, \beta=-0.714)$ between higher education and continuous training (ef_het) and entrepreneurial behavior (E_BHV); a direct and significant negative relationship $(p=0.000<0.05$, $\beta=-0.770$ ) between market size (ef_ms) and entrepreneurial behavior (E_BHV); positive, direct and significant relationships ( $\mathrm{p}_{\mathrm{e} \_a s p}=0.003, \mathrm{p}_{\mathrm{e} \_ \text {atp }}=0.000<0.05, \beta_{\mathrm{e} \_ \text {act }}=1 *$ constrained, $\left.\beta_{\mathrm{e} \_a s p}=2.777, \beta_{\mathrm{e} \_a t p}=2.608\right)$ between entrepreneurial activity $\left(\mathrm{e} \_a c t\right)$, entrepreneurial aspiration (e_asp), entrepreneurial attitude and perceptions (e_atp) and entrepreneurial behavior as latent variable (E_BHV); and a positive and significant relationship $(p \approx 0.05, \tau=0.829)$ between the entrepreneurial behavior (E_BHV) and increase of imports (ch_imp). Subsequently, hypothesis H1 is partially valid and hypothesis $\mathrm{H} 3$ is valid.

Table 7. SEM results for the research model with MLMV estimation method and four-year delay.

\begin{tabular}{|c|c|c|c|c|c|c|c|c|c|c|c|c|c|}
\hline \multirow{2}{*}{\multicolumn{2}{|c|}{ Analyzed Relations }} & \multicolumn{3}{|c|}{ Model 1} & \multicolumn{3}{|c|}{ Model 2} & \multicolumn{3}{|c|}{ Model 3} & \multicolumn{3}{|c|}{ Model 4} \\
\hline & & Coef. & $\mathbf{Z}$ & $\mathbf{P}$ & Coef. & $\mathbf{Z}$ & $\mathbf{P}$ & Coef. & $\mathbf{Z}$ & $\mathbf{P}$ & Coef. & $\mathbf{Z}$ & $\mathbf{P}$ \\
\hline \multirow{6}{*}{$\begin{array}{c}\text { E_BHV } \\
\leftarrow\end{array}$} & ef_het & -0.899 & -3.19 & 0.001 & -0.714 & -2.28 & 0.023 & -0.703 & -2.46 & 0.014 & -0.586 & -1.60 & 0.110 \\
\hline & ef_gme & 1.271 & 3.45 & 0.001 & 0.824 & 1.78 & 0.076 & 1.044 & 2.68 & 0.007 & 0.314 & 0.66 & 0.506 \\
\hline & ef_lme & -0.062 & -0.31 & 0.755 & -0.142 & -0.64 & 0.523 & -0.122 & -0.61 & 0.544 & -0.213 & -0.85 & 0.394 \\
\hline & ef_fme & -0.022 & -0.08 & 0.935 & 0.370 & 1.40 & 0.160 & 0.273 & 1.15 & 0.250 & 0.674 & 2.89 & 0.004 \\
\hline & ef_tr & 0.115 & 0.64 & 0.521 & 0.045 & 0.21 & 0.833 & -0.168 & -0.85 & 0.396 & 0.101 & 0.41 & 0.678 \\
\hline & ef_ms & -0.644 & -3.54 & 0.000 & -0.770 & -5.47 & 0.000 & -0.680 & -4.51 & 0.000 & -0.765 & -5.38 & 0.000 \\
\hline \multirow{3}{*}{$\begin{array}{l}\text { e_act } \\
\text { e_asp } \\
\text { e_atp }\end{array}$} & & $1 *$ & & & $1 *$ & & & $1 *$ & & & $1 *$ & & \\
\hline & $\leftarrow$ E_BHV & 4.060 & 2.85 & 0.004 & 2.777 & 2.94 & 0.003 & 3.193 & 3.06 & 0.002 & 1.783 & 2.84 & 0.005 \\
\hline & & 2.522 & 4.21 & 0.000 & 2.608 & 5.01 & 0.000 & 2.804 & 4.67 & 0.000 & 2.611 & 5.20 & 0.000 \\
\hline \multirow{4}{*}{$\begin{array}{l}\text { ch_gdp } \\
\text { ch_imp } \\
\text { ch_exp } \\
\text { ch_emp }\end{array}$} & $\leftarrow$ E_BHV & 0.729 & 2.10 & 0.036 & & & & & & & & & \\
\hline & $\leftarrow$ E_BHV & & & & 0.829 & 1.94 & 0.053 & & & & & & \\
\hline & $\leftarrow$ E_BHV & & & & & & & 1.332 & 2.55 & 0.011 & & & \\
\hline & $\leftarrow$ E_BHV & & & & & & & & & & -0.066 & -1.19 & 0.236 \\
\hline
\end{tabular}

Note: Coef. = path estimate coefficient; $\mathrm{Z}=$ critical ratio; $\mathrm{P}=$ significance level; ${ }^{*}=$ constrain.

Considering the results of modeling four-year lagged effects on the growth of exports of goods and services (Model 3), the next influences are essential: a direct and significant negative relationship $(p=0.014<0.05, \beta=-0.703)$ between higher education and continuing training (ef_het) and entrepreneurial behavior (E_BHV); a positive and direct positive relationship $(p=0.007<0.05, \beta=1.044)$ between the efficiency of goods market (ef_gme) and entrepreneurial behavior (E_BHV); positive, direct and significant relationships ( $\mathrm{p}_{\mathrm{e} \_a s p}=0.002, \mathrm{p}_{\mathrm{e} \_ \text {atp }}=0.000<0.05, \beta_{\mathrm{e} \_a c t}=1{ }^{*}$ constrained, $\left.\beta_{\mathrm{e} \_a s p}=3.193, \beta_{\mathrm{e} \_a t p}=2.804\right)$ between entrepreneurial activity $\left(\mathrm{e} \_a c t\right)$, entrepreneurial aspiration (e_asp), entrepreneurial attitude and perceptions (e_atp) and entrepreneurial behavior as latent variable (E_BHV); and a positive and significant relationship $(p=0.011<0.05, \tau=1.332)$ between the entrepreneurial behavior (E_BHV) and increase of exports, as a dependent variable (ch_exp). Therefore, hypothesis $\mathrm{H} 1$ is partially valid and hypothesis $\mathrm{H} 4$ is valid.

About the total effects studied with a four-year gap on the growth of employed population (Model $4)$, the statistical findings show: a positive, direct and significant relationship $(p=0.004<0.05, \beta=0.674)$ between the financial market development and sophistication (ef_fmd) and entrepreneurial behavior (E_BHV); a negative, direct and significant relationship $(p=0.000<0.05, \beta=-0.765)$ between market size (ef_ms) and entrepreneurial behavior (E_BHV); and positive, direct and significant relationships $\left(\mathrm{p}_{\mathrm{e} \_a s p}=0.005, \mathrm{p}_{\mathrm{e} \_ \text {atp }}=0.000<0.05, \beta_{\mathrm{e} \_ \text {act }}=1 *\right.$ constrained, $\left.\beta_{\mathrm{e} \_ \text {asp }}=1.783, \beta_{\mathrm{e} \_a t p}=2.611\right)$ between entrepreneurial activity (e_act), entrepreneurial aspiration (e_asp), entrepreneurial attitude and perceptions (e_atp) and entrepreneurial behavior as latent variable (E_BHV). In these circumstances, hypothesis $\mathrm{H} 1$ is considered partially valid, whereas hypothesis $\mathrm{H} 5$ is not valid.

Referring to models with five-year lagged effects, data analysis of the specific SEM supports a series of statistically significant relationships for the conditions of efficiency-driven framework and entrepreneurial behavior, together with their impact on economic growth, imports and exports (Table 8). 
Table 8. SEM results for the research model with MLMV estimation method and five-year delay.

\begin{tabular}{|c|c|c|c|c|c|c|c|c|c|c|c|c|c|}
\hline \multirow{2}{*}{\multicolumn{2}{|c|}{ Analyzed Relations }} & \multicolumn{3}{|c|}{ Model 1} & \multicolumn{3}{|c|}{ Model 2} & \multicolumn{3}{|c|}{ Model 3} & \multicolumn{3}{|c|}{ Model 4} \\
\hline & & Coef. & $\mathrm{Z}$ & $\mathbf{P}$ & Coef. & $\mathrm{Z}$ & $\mathbf{P}$ & Coef. & $\mathrm{Z}$ & $\mathbf{P}$ & Coef. & $\mathbf{Z}$ & $\mathbf{P}$ \\
\hline \multirow{6}{*}{$\begin{array}{c}\text { E_BHV } \\
\leftarrow\end{array}$} & ef_het & -0.917 & -3.18 & 0.001 & -0.813 & -2.59 & 0.010 & -0.861 & -2.82 & 0.005 & -0.713 & -2.02 & 0.043 \\
\hline & ef_gme & 1.089 & 2.75 & 0.006 & 0.760 & 1.68 & 0.093 & 0.864 & 2.00 & 0.046 & 0.415 & 0.85 & 0.393 \\
\hline & ef_lme & -0.016 & -0.07 & 0.940 & -0.121 & -0.53 & 0.595 & -0.121 & -0.55 & 0.579 & -0.177 & -0.71 & 0.480 \\
\hline & ef_fmd & 0.021 & 0.08 & 0.940 & 0.334 & 1.28 & 0.199 & 0.341 & 1.36 & 0.174 & 0.600 & 2.47 & 0.014 \\
\hline & ef_tr & 0.184 & 0.96 & 0.336 & 0.170 & 0.81 & 0.417 & 0.033 & 0.16 & 0.873 & 0.164 & 0.71 & 0.480 \\
\hline & ef_ms & -0.700 & -4.25 & 0.000 & -0.798 & -5.75 & 0.000 & -0.742 & -5.25 & 0.000 & -0.802 & -6.00 & 0.000 \\
\hline \multirow{3}{*}{$\begin{array}{l}\text { e_act } \\
\text { e_asp } \\
\text { e_atp }\end{array}$} & & $1 *$ & & & $1 *$ & & & $1 *$ & & & $1^{*}$ & & \\
\hline & $\leftarrow$ E_BHV & 3.557 & 3.03 & 0.002 & 2.754 & 3.09 & 0.002 & 2.840 & 3.05 & 0.002 & 2.047 & 2.88 & 0.004 \\
\hline & & 2.431 & 4.48 & 0.000 & 2.473 & 4.99 & 0.000 & 2.626 & 4.98 & 0.000 & 2.525 & 5.29 & 0.000 \\
\hline \multirow{4}{*}{$\begin{array}{l}\text { ch_gdp } \\
\text { ch_imp } \\
\text { ch_exp } \\
\text { ch_emp }\end{array}$} & $\leftarrow$ E_BHV & 0.675 & 2.47 & 0.013 & & & & & & & & & \\
\hline & $\leftarrow$ E_BHV & & & & 0.865 & 2.48 & 0.013 & & & & & & \\
\hline & $\leftarrow$ E_BHV & & & & & & & 0.877 & 2.60 & 0.009 & & & \\
\hline & $\leftarrow$ E_BHV & & & & & & & & & & 0.009 & 0.20 & 0.842 \\
\hline
\end{tabular}

Note: Coef. $=$ path estimate coefficient; $\mathrm{Z}=$ critical ratio; $\mathrm{P}=$ significance level; ${ }^{*}=$ constrain.

In the case of structuring direct and indirect relations with impact on economic growth shifted by five years (Model 1), the following results are noteworthy: a negative, direct and statistically significant relationship ( $p=0.001<0.05, \beta=-0.917$ ) between higher education and continuous training (ef_het) and entrepreneurial behavior (E_BHV); a positive, direct and significant relationship $(p=0.006<0.05$, $\beta=1.089$ ) between the goods market efficiency (ef_gme) and entrepreneurial behavior (E_BHV); a direct and significant negative relationship $(p=0.000<0.05, \beta=-0.700)$ between market size (ef_ms) and entrepreneurial behavior (E_BHV); positive, direct and significant relationships ( $\mathrm{p}_{\mathrm{e} \_a s p}=0.002$, $p_{\mathrm{e} \_a t p}=0.000<0.05, \beta_{\mathrm{e} \_a c t}=1 *$ constrained, $\left.\beta_{\mathrm{e} \_a s p}=3.557, \beta_{\mathrm{e} \_a t p}=2.431\right)$ between entrepreneurial activity (e_act), entrepreneurial aspiration (e_asp), entrepreneurial attitude and perceptions (e_atp) and entrepreneurial behavior as latent variable (E_BHV); and a positive and significant relationship $(p=0.013<0.05, \tau=0.675$ ) between the entrepreneurial behavior (E_BHV) and the economic growth measured as the change of gross domestic product (ch_gdp). Accordingly, hypothesis H1 is partially valid and hypothesis $\mathrm{H} 2$ is valid.

Applying the research model with five-year lagged effects on the growth of imports of goods and services (Model 2), results highlight: a direct and significant negative relationship $(p=0.000<0.05$, $\beta=-0.813$ ) between higher education and continuous training (ef_het)and entrepreneurial behavior (E_BHV); a direct and significant negative relationship $(p=0.000<0.05, \beta=-0.798)$ between market size (ef_ms) and entrepreneurial behavior (E_BHV); positive, direct and significant relationships $\left(\mathrm{p}_{\mathrm{e} \_a s p}=0.002, \mathrm{p}_{\mathrm{e} \_a t p}=0.000<0.05, \beta_{\mathrm{e} \_ \text {act }}=1{ }^{*}\right.$ constrained, $\left.\beta_{\mathrm{e} \_ \text {asp }}=2.754, \beta_{\mathrm{e} \_ \text {atp }}=2.473\right)$ between entrepreneurial activity (e_act), entrepreneurial aspiration (e_asp), entrepreneurial attitude and perceptions (e_atp) and entrepreneurial behavior as latent variable (E_BHV); and a positive and significant relationship $(p=0.013<0.05, \tau=0.865)$ between the entrepreneurial behavior $\left(E_{-} B H V\right)$ and increase of imports (ch_imp). Consequently, hypothesis H1 is partially valid and hypothesis H3 is valid.

In the case of considering both direct and indirect influences shifted by five years on the growth of exports of goods and services (Model 3 ), the following aspects are statistically confirmed: a direct and significant negative relationship $(p=0.005<0.05, \beta=-0.861)$ between higher education and training (ef_het) and entrepreneurial behavior (E_BHV); a positive, direct and significant relationship $(p=0.046<0.05, \beta=0.864$ ) between products market efficiency (ef_gme) and entrepreneurial behavior (E_BHV); a negative and direct relationship $(p=0.000<0.05, \beta=-0.742)$ between market size (ef_ms) and entrepreneurial behavior (E_BHV); positive, direct and significant relationships ( $\mathrm{p}_{\mathrm{e} \_a s p}=0.002$, $\mathrm{p}_{\mathrm{e} \_ \text {atp }}=0.000<0.05, \beta_{\mathrm{e} \_ \text {act }}=1 *$ constrained, $\left.\beta_{\mathrm{e} \_ \text {asp }}=2.84, \beta_{\mathrm{e} \_ \text {atp }}=2.626\right)$ between entrepreneurial activity (e_act), entrepreneurial aspiration (e_asp), entrepreneurial attitude and perceptions (e_atp) and entrepreneurial behavior as latent variable (E_BHV); and positive and significant relationship $(p=0.009<0.05, \tau=0.877)$ between the entrepreneurial behavior (E_BHV) and the dependent variable 
increase of exports (ch_exp). The obtained results allow a partial validation of hypothesis $\mathrm{H} 1$ and the validation of hypothesis $\mathrm{H} 4$.

Studying the total effects on the growth of the employed population (Model 4) with a five-year gap, the following relations proved significance: a direct negative relationship $(p=0.043<0.05, \beta=-0.713)$ between higher education and continuous training (ef_het) and entrepreneurial behavior(E_BHV); a positive and direct relationship ( $p=0.014<0.05 ; \beta=0.600$ ) between the degree of financial market sophistication and development (ef_fme) and entrepreneurial behavior (E_BHV); a negative and direct relationship ( $p=0.000<0.05, \beta=-0.802$ ) between market size (ef_ms) and entrepreneurial behavior $\left(\mathrm{E} \_B H V\right)$; and positive, direct and significant relationships $\left(\mathrm{p}_{\mathrm{e} \_a s p}=0.004, \mathrm{p}_{\mathrm{e} \_ \text {atp }}=0.000<0.05, \beta_{\mathrm{e} \_ \text {act }}=1\right.$ ${ }^{*}$ constrained, $\left.\beta_{\mathrm{e} \_a s p}=2.047, \beta_{\mathrm{e} \_a t p}=2.525\right)$ between entrepreneurial activity (e_act), entrepreneurial aspiration (e_asp), entrepreneurial attitude and perceptions (e_atp) and entrepreneurial behavior as latent variable (E_BHV). In the above context, hypothesis H1is partially valid and hypothesis H5 is refuted.

The results of testing research assumptions on a panel of 33 European countries showed that some of the research hypotheses were fully or partially valid (Table 9).

Table 9. Synopsis of empirical results regarding the research hypotheses.

\begin{tabular}{|c|c|c|c|c|}
\hline $\begin{array}{c}\text { Studied } \\
\text { Macroeconomic Effect } \\
\text { Type of Analysis }\end{array}$ & Economic Growth & $\begin{array}{l}\text { Increase of } \\
\text { Imports }\end{array}$ & $\begin{array}{l}\text { Increase of } \\
\text { Exports }\end{array}$ & $\begin{array}{c}\text { Evolution of } \\
\text { Employed Population }\end{array}$ \\
\hline $\begin{array}{l}\text { Simultaneous } \\
\text { influence }\end{array}$ & $\begin{array}{l}\text { H1 partial valid } \\
\text { H2 valid }\end{array}$ & H1 partial valid & $\begin{array}{l}\text { H1 partial valid } \\
\text { H4 valid }\end{array}$ & $\begin{array}{l}\text { H1 partial valid } \\
\text { H5 valid }\end{array}$ \\
\hline 1-year delay & H1 partial valid & H1 partial valid & H1 partial valid & H1 partial valid \\
\hline 2-year delay & H1 partial valid & H1 partial valid & H1 partial valid & H1 partial valid \\
\hline 3-year delay & H1 partial valid & H1 partial valid & $\begin{array}{l}\text { H1 partial valid } \\
\text { H4 valid }\end{array}$ & H1 partial valid \\
\hline 4-year delay & $\begin{array}{l}\text { H1 partial valid } \\
\text { H2 valid }\end{array}$ & $\begin{array}{l}\text { H1 partial valid } \\
\text { H3 valid }\end{array}$ & $\begin{array}{l}\text { H1 partial valid } \\
\text { H4 valid }\end{array}$ & H1 partial valid \\
\hline 5-year delay & $\begin{array}{l}\text { H1 partial valid } \\
\text { H2 valid }\end{array}$ & $\begin{array}{l}\text { H1 partial valid } \\
\text { H3 valid }\end{array}$ & $\begin{array}{l}\text { H1 partial valid } \\
\text { H4 valid }\end{array}$ & H1 partial valid \\
\hline
\end{tabular}

In the case of the analyzed countries, a higher level of economic efficiency framework conditions has positive simultaneous and medium-term sustainable influences on entrepreneurial behavior. The conditions of the entrepreneurial framework stimulate the entrepreneurial behavior according to several studies $[1,24,25]$. The market size has a negative simultaneous and medium-run impact on entrepreneurial behavior at the level of the panel countries and is only stimulating for large and established firms with national activity, behavior which was not taken into account within the research.

Entrepreneurial behavior has the potential to create economic and non-economic value for the environmental, economic and social dimension of sustainability $[30,55]$. The obtained immediate and medium-term results probe the entrepreneurial positive effects from economic and social perspectives.

An increased level of entrepreneurial behavior generates economic growth both simultaneously and continuously preserved on medium-run in the case of the countries included in the panel, confirming the results of other empirical research [17,31-35].

A high level of manifestation of entrepreneurial behavior has positive, direct and simultaneous effects on the labor market, increasing the number of employed population according to the empirical findings registered by other studies [32,42,45,46]. Implications for the labor market are the results of interactions between market entry and exit effects $[11,56]$. The entry of new firms into the market simultaneously results in the growth of the employed population as effect of opportunity discovery and exploitation, and voluntary or necessity driven self-employment of people with entrepreneurial skills and intent. However, in the medium-term, the entry of new firms on the market intensifies 
competition and generates the elimination of lower-performing entrepreneurial businesses, creating and destroying jobs [11].

A superior level of entrepreneurial behavior stimulates in medium-term the sustainable implication in foreign trade of the European countries from the panel, with instantaneous positive effect only on exports. The exclusive simultaneous growth of exports highlights a behavior oriented towards a rapid internationalization of entrepreneurs in the process of starting a new business and managing small- and medium-sized firms. In the short-term, entrepreneurial behavior is highlighted in the incremental internalization process, oriented towards the internal market. In the medium-term, entrepreneurs within the process of initiating a new business or running small- and medium-sized firms exhibit ambidextrous behavior characterized by both rapid and incremental internationalization. The empirical results highlight the need to further pursue empirical research, especially in transition and emerging countries [37,38].

\section{Conclusions, Limits and Future Research Directions}

Testing the research assumptions generated the idea that, at the level of developed and emerging countries from the panel, a national efficiency-driven framework is incentive for entrepreneurial behavior of nascent entrepreneurs, of new small- and medium-sized business owners, while a higher level of entrepreneurial behavior generates concurrent and/or medium-term favorable effects on gross domestic product, exports, imports and employment. Further, the continuous positive evolution of the macroeconomic effects indicates a potentially sustainable growth of the panel countries. Largely, the causal relationships identified are consistent with the results of other already existing empirical research.

The design of the research model rests on the GEM Consortium (2008) [2] reference model. However, the proposed model is not of replicative type; the links between the constructs that make it operational, the extension of the scope and of the macroeconomic level entrepreneurial effects allowed for a deductive approach of the empirical research, and to highlight the influences of the conditions of the economic efficiency-driven framework on entrepreneurial behavior; the positive macroeconomic effects of entrepreneurial behavior on the level of economic development, to the degree of internationalization of entrepreneurial firms; and on the growth of the employed population in 33 European countries with a time lag of up to five-years.

For academics, the model can be used as a theoretical framework for future deductive empirical research, on the one hand, with the aim of conducting cross-country comparative studies, identifying good case practices in the field of entrepreneurship and entrepreneurial management, developing policies to stimulate and support entrepreneurial behavior of individuals and the activity of small- and medium-sized entrepreneurial firms, and, on the other hand, for studying the inverse stimuli effects of economic growth on the entrepreneurial behavior.

In the context of the New Lisbon Strategy and the Europe 2020 Strategy, the results of the present study show that incentive policies for existing entrepreneurship are needed, but they do not automatically manifest themselves as factors of internal or external economic growth and social progress, based on the improvement of domestic and foreign value added, and the development of employment. For nascent entrepreneurs and managers of small- and medium-sized entrepreneurial firms from the concerned European countries, the theoretical framework and the results of the present research provide information to stimulate their initiatives and improve their ability to perceive the multiple facets of entrepreneurship, and to initiate and consolidate resource combinatory processes allowing and resulting in competitive advantage gains and increased firm level performance. The research limits are set by the limited nature of the time series for which the analysis is conducted, the MLMV method relaxations, the exclusion of the large firms from the analysis, along with the lack of a comparative study on the macroeconomic effects of entrepreneurial behavior on categories of European countries according to their economic development level, and on extended panels of pan-European, Asian and North American countries. Removing these limits would extend the scope 
of analyzing entrepreneurship in an international context and increase the quality of conclusions resulting from the statistical analysis of available data, with positive effects in setting benchmark practices, incentives and support policies in the field of entrepreneurship at international level. A prospective research avenue consists in segmenting the research model on traditional, social and eco-entrepreneurship [57] niches, allowing for a more profound search on the specific determinants of sustainable entrepreneurship [30], to explore sustainable opportunities and venture creation, along with their sustainable macroeconomic effects, as a combination of positive environmental, economic and social results at national and regional levels.

Author Contributions: Renata Dana NITU-ANTONIE (first and corresponding author) is assistant professor and Director of the Marketing and International Economic Relations Department with keen interest in entrepreneurship from European and international perspective. As first author, she designed the conceptual model of the research, assessed the specific entrepreneurial literature and created the introduction and the literature review for the paper. Emőke-Szidónia FEDER (second author) is lecturer with expertise in international entrepreneurship and business research, and acted as responsible for the empirical part of the paper, therefore she collected secondary data for the research model, designed the data analysis method and performed the empirical data analysis with SEM in Stata and interpreted the results. Valentin Partenie MUNTEANU (third author) is assistant professor and Director of the Management Department, specialized in business ethics and management. He acted as consultant in sustainability related challenges, discussed the empirical results in correlation with other studies, conceived the conclusions, limits and future directions of the research. Each author fashioned a first draft of the mentioned sections, afterwards collectively improved the paper.

Conflicts of Interest: The authors declare no conflict of interest.

\section{Appendix A}

Table A1. SEM results for the research model with MLMV estimation method and one-year delay.

\begin{tabular}{|c|c|c|c|c|c|c|c|c|c|c|c|c|c|}
\hline \multirow{2}{*}{\multicolumn{2}{|c|}{ Analyzed Relations }} & \multicolumn{3}{|c|}{ Model 1} & \multicolumn{3}{|c|}{ Model 2} & \multicolumn{3}{|c|}{ Model 3} & \multicolumn{3}{|c|}{ Model 4} \\
\hline & & Coef. & $\mathbf{Z}$ & $\mathbf{P}$ & Coef. & $\mathbf{Z}$ & $\mathbf{P}$ & Coef. & $\mathbf{Z}$ & $\mathbf{P}$ & Coef. & $\mathbf{Z}$ & $\mathbf{P}$ \\
\hline \multirow{6}{*}{$\begin{array}{c}\text { E_BHV } \\
\leftarrow\end{array}$} & ef_het & -0.722 & -2.07 & 0.038 & -0.694 & -1.99 & 0.046 & -0.718 & -2.04 & 0.041 & -0.701 & -2.00 & 0.045 \\
\hline & ef_gme & 0.496 & 1.02 & 0.308 & 0.384 & 0.80 & 0.422 & 0.394 & 0.80 & 0.426 & 0.399 & 0.82 & 0.410 \\
\hline & ef_lme & -0.136 & -0.55 & 0.586 & -0.201 & -0.81 & 0.418 & -0.152 & -0.61 & 0.545 & -0.187 & -0.75 & 0.451 \\
\hline & ef_fme & 0.545 & 2.22 & 0.026 & 0.632 & 2.63 & 0.008 & 0.564 & 2.30 & 0.022 & 0.611 & 2.54 & 0.011 \\
\hline & ef_tr & 0.129 & 0.55 & 0.581 & 0.163 & 0.70 & 0.481 & 0.183 & 0.78 & 0.437 & 0.164 & 0.70 & 0.482 \\
\hline & ef_ms & -0.789 & -5.85 & 0.000 & -0.796 & -5.92 & 0.000 & -0.818 & -6.12 & 0.000 & -0.801 & -5.98 & 0.000 \\
\hline \multirow{3}{*}{$\begin{array}{l}\text { e_act } \\
\text { e_asp } \\
\text { e_atp }\end{array}$} & & $1 *$ & & & $1 *$ & & & $1 *$ & & & $1 *$ & & \\
\hline & $\leftarrow$ E_BHV & 2.069 & 2.98 & 0.003 & 2.008 & 2.96 & 0.003 & 2.026 & 2.95 & 0.003 & 2.016 & 2.95 & 0.003 \\
\hline & & 2.528 & 5.28 & 0.000 & 2.552 & 5.29 & 0.000 & 2.446 & 5.21 & 0.000 & 2.527 & 5.29 & 0.000 \\
\hline ch_gdp & $\leftarrow$ E_BHV & 0.299 & 1.26 & 0.207 & & & & & & & & & \\
\hline ch_imp & $\leftarrow$ E_BHV & & & & -0.295 & -0.53 & 0.559 & & & & & & \\
\hline ch_exp & $\leftarrow$ E_BHV & & & & & & & 0.532 & 1.18 & 0.239 & & & \\
\hline ch_emp & $\leftarrow$ E_BHV & & & & & & & & & & -0.005 & -0.07 & 0.944 \\
\hline
\end{tabular}

Note: Coef. = path estimate coefficient; $\mathrm{Z}=$ critical ratio; $\mathrm{P}=$ significance level; ${ }^{*}=$ constrain.

Table A2. SEM results for the research model with MLMV estimation method and two-year delay.

\begin{tabular}{|c|c|c|c|c|c|c|c|c|c|c|c|c|c|}
\hline \multirow{2}{*}{\multicolumn{2}{|c|}{ Analyzed Relations }} & \multicolumn{3}{|c|}{ Model 1} & \multicolumn{3}{|c|}{ Model 2} & \multicolumn{3}{|c|}{ Model 3} & \multicolumn{3}{|c|}{ Model 4} \\
\hline & & Coef. & $\mathbf{Z}$ & $\mathbf{P}$ & Coef. & $\mathbf{Z}$ & $\mathbf{P}$ & Coef. & $\mathbf{Z}$ & $\mathbf{P}$ & Coef. & $\mathbf{Z}$ & $\mathbf{P}$ \\
\hline \multirow{6}{*}{$\begin{array}{c}\text { E_BHV } \\
\leftarrow\end{array}$} & ef_het & -0.763 & -2.08 & 0.037 & -0.721 & -2.00 & 0.046 & -0.832 & -2.32 & 0.020 & -0.555 & -1.55 & 0.121 \\
\hline & ef_gme & 0.420 & 0.85 & 0.396 & 0.402 & 0.83 & 0.409 & 0.340 & 0.68 & 0.496 & 0.363 & 0.80 & 0.422 \\
\hline & ef_lme & -0.165 & -0.65 & 0.513 & -0.182 & -0.73 & 0.466 & -0.136 & -0.54 & 0.592 & -0.226 & -0.95 & 0.343 \\
\hline & ef_fme & 0.572 & 2.28 & 0.023 & 0.601 & 2.47 & 0.013 & 0.550 & 2.22 & 0.026 & 0.674 & 2.94 & 0.003 \\
\hline & ef_tr & 0.212 & 0.85 & 0.398 & 0.183 & 0.72 & 0.469 & 0.292 & 1.18 & 0.238 & 0.066 & 0.28 & 0.778 \\
\hline & ef_ms & -0.808 & -6.03 & 0.000 & -0.806 & -5.96 & 0.000 & -0.821 & -6.18 & 0.000 & -0.766 & -5.55 & 0.000 \\
\hline \multirow{3}{*}{$\begin{array}{l}\text { e_act } \\
\text { e_asp } \\
\text { e_atp }\end{array}$} & & $1 *$ & & & $1 *$ & & & $1 *$ & & & $1 *$ & & \\
\hline & $\leftarrow$ E_BHV & 2.030 & 2.96 & 0.003 & 2.020 & 2.95 & 0.003 & 2.023 & 2.98 & 0.003 & 1.972 & 2.90 & 0.004 \\
\hline & & 2.462 & 5.12 & 0.000 & 2.502 & 5.15 & 0.000 & 2.390 & 5.17 & 0.000 & 2.717 & 5.16 & 0.000 \\
\hline ch_gdp & $\leftarrow$ E_BHV & 0.140 & 0.59 & 0.555 & & & & & & & & & \\
\hline ch_imp & $\leftarrow$ E_BHV & & & & 0.118 & 0.21 & 0.832 & & & & & & \\
\hline ch_exp & $\leftarrow$ E_BHV & & & & & & & 0.737 & 1.70 & 0.090 & & & \\
\hline ch_emp & $\leftarrow$ E_BHV & & & & & & & & & & -0.115 & -1.30 & 0.192 \\
\hline
\end{tabular}

Note: Coef. $=$ path estimate coefficient; $\mathrm{Z}=$ critical ratio; $\mathrm{P}=$ significance level; ${ }^{*}=$ constrain. 


\section{References}

1. Sala-I, M.X.; Blanke, J.; Drzeniek, M.; Geiger, T.; Mia, I. Global Competitiveness Report 2009-2010; World Economic Forum: Geneva, Switzerland, 2009; pp. 1-492. Available online: http:/ /www3.weforum. org/docs/WEF_GlobalCompetitivenessReport_2009-10.pdf (accessed on 18 October 2016).

2. Bosma, N.; Ács, Z.J.; Autio, E.; Coduras, A.; Levie, J. Global Entrepreneurship Monitor 2008_Executive Report; Babson College, Universidad del Desarrollo, London Business School, Global Entrepreneurship Research Consortium: London, UK, 2009; pp. 1-68.

3. Schwab, K.; Porter, M. The Global Competitiveness Report 2008-2009; World Economic Forum: Geneva, Switzerland, 2008; pp. 1-500. Available online: https://www.weforum.org/reports/global-competitivenessreport-2008-2009 (accessed on 12 July 2016).

4. Shane, S.; Venkataraman, S. The Promise of Entrepreneurship as a Field of Research. Acad. Manag. Rev. 2000, 25, 217-226. Available online: https://www.jstor.org/stable/259271 (accessed on 22 May 2016). [CrossRef]

5. Kirzner, I.M. Competition and Entrepreneurship; The University of Chicago Press: Chicago, IL, USA; London, UK, 1973; pp. 1-242.

6. Kirzner, I.M. Information-Knowledge and Action-Knowledge. Econ. J. Watch. 2005, 2, 75-81. Available online: https:/ / econjwatch.org/file_download/70/2005-04-kirzner-sympos.pdf?mimetype=pdf (accessed on 18 October 2016).

7. Facchini, F. Entrepreneur et Croissance Économique: Développements Récents. Revue D'écon. Ind. 2007, 119, 55-84. Available online: https:/ / rei.revues.org/2033?lang=en (accessed on 10 June 2016). [CrossRef]

8. Minniti, M.; Koppl, R. The Unitended Consequences of Entrepreneurship. J. Écon. Études Hum. 1999, 9, 567-586. Available online: https://www.degruyter.com/view/j/jeeh.1999.9.issue-4/jeeh-1999-0406/jeeh1999-0406.xml (accessed on 18 October 2016). [CrossRef]

9. Minniti, M. Entrepreneurship and network externalities. J. Econ. Behav. Organ. 2005, 57, 1-27. Available online: http:/ / mail.imb.usu.ru/docs/Bank\%20English_Transleted\%20Articles/English/Enterprenurship/ Entrepreneurship\%20and\%20network\%20externalities.pdf (accessed on 18 October 2016). [CrossRef]

10. Audretsch, D.B.; Keilbach, M.C.; Lehmann, E.E. Entrepreneurship and Economic Growth; Oxford University Press: New York, NY, USA, 2006; pp. 34-59.

11. Nițu-Antonie, R.D. Entrepreneurship in an International Perspective. In Postdoctoral Studies in Economy; Romanian Academy Publishing House: Bucharest, Romania, 2013; Volume 6, pp. 1256-1317.

12. Keh, H.T.; Foo, M.D.; Lim, B.C. Opportunity Evaluation under Risky Conditions: The Cognitive Processes of Entrepreneurs. Entrep. Theory Pract. 2002, 27, 125-140. Available online: http://onlinelibrary.wiley.com/ doi/10.1111/1540-8520.00003/abstract (accessed on 12 July 2016). [CrossRef]

13. Davidsson, P.; Delmar, F. High-growth Firms and their Contribution to Employment: The Case of Sweden 1987-96. In Entrepreneurship and the Growth of Firms; Davidsson, P., Delmar, F., Wiklund, J., Eds.; Edward Elgar: Cheltenham, UK, 2006; pp. 156-178.

14. Audretsch, D.; Thurik, R. Linking Entrepreneurship to Growth. OECD Sci. Technol. Ind. Work. Pap. 2001, 2, 1-34. Available online: http://www.oecd-ilibrary.org/docserver/download/736170038056.pdf?expires= 1498363434\&id=id\&accname=guest\&checksum=AA42EA126C3562DE20D443D59BC12651 (accessed on 10 June 2016). [CrossRef]

15. Baptista, R.; Escária, V.; Madruga, P. Entrepreneurship, regional development and job creation: The case of Portugal. Small Bus. Econ. 2008, 30, 49-58. Available online: https://link.springer.com/article/10.1007/ s11187-007-9055-0 (accessed on19 January 2017). [CrossRef]

16. Baptista, R.; Thurik, A. Relationship between Entrepreneurship and Employment: Is Portugal an Outlier? Technol. Soc. Chang. 2007, 75, 75-89. Available online: http://www.sciencedirect.com/science/article/pii/ S0040162506000849 (accessed on 12 July 2016). [CrossRef]

17. González-Pernía, J.L.; Peña-Legazkue, I. Export-oriented entrepreneurship and regional economic growth. Small Bus. Econ. 2015, 45, 505-522. Available online: http://link.springer.com/article/10.1007/s11187-0159657-x (accessed on 5 March 2017). [CrossRef]

18. Ravasi, D.; Turati, C. Exploring Entrepreneurial Learning: A Comparative Study of Technology Development Projects. J. Bus. Ventur. 2005, 20, 137-164. Available online: http:/ /www.sciencedirect.com/science/article/ pii/S0883902603001198 (accessed on 19 January 2017). [CrossRef] 
19. Newbert, S.L. New Firm Formation: A dynamic capability perspective. Small Bus. Manag. 2005, 43, 55-77. Available online: http://onlinelibrary.wiley.com/doi/10.1111/j.1540-627X.2004.00125.x/abstract (accessed on 12 July 2016). [CrossRef]

20. Lumpkin, G.; Dess, G. Clarifying the Entrepreneurial Orientation Construct and Linking it to Performance. Acad. Manag. Rev. 1996, 21, 135-172. Available online: http://www.jstor.org/stable/258632 (accessed on 10 June 2016).

21. Autio, E. Global Entrepreneurship Monitor: 2007 Global Report on High-Growth Entrepreneurship; Babson College: Babson Park, FL, USA; London Business School; Global Entrepreneurship Research Consortium: London, UK, 2007; pp. 1-48.

22. Hessels, J. International Entrepreneurship: Value Creation across National Borders. Ph.D. Thesis, Erasmus Research Institute of Management Erasmus University, Rotterdam, The Netherlands, 2008.

23. Feder, E.S. International Market, Entrepreneurial and Learning Orientations as Drivers of Firm Performance. Stud. Univ. Babes Bolyai. 2015, 60, 3-22. Available online: http://studia.ubbcluj.ro/download/pdf/919.pdf (accessed on 18 October 2016).

24. Bosma, N.; Jones, K.; Autio, E.; Levie, J. Global Entrepreneurship Monitor 2007-Executive Report; Babson College: Babson Park, FL, USA; London Business School; Global Entrepreneurship Research Consortium: London, UK, 2008; pp. 1-66.

25. Ács, Z.J.; Dana, L.P.; Jones, M.V. Toward New Horizons: The Internationalisation of Entrepreneurship. J. Int. Entrep. 2003, 1, 5-12. Available online: http:/ /link.springer.com/article/10.1023/A\%3A1023257414794 (accessed on 5 March 2017). [CrossRef]

26. Morgan, R.E.; Strong, C.A. Market orientation and dimensions of strategic orientation. Eur. J. Market. 1998, 32, 1051-1073. Available online: http:/ / www.emeraldinsight.com/doi/abs/10.1108/03090569810243712 (accessed on 19 January 2017). [CrossRef]

27. Slater, S.; Narver, J. Does Competitive Environment Moderate the Market orientation-Performance Relationship? J. Market. 1994, 58, 46-55. Available online: http://www.jstor.org/stable/1252250 (accessed on 12 July 2016). [CrossRef]

28. Deng, S.; Dart, J. Measuring Market Orientation: A Multi-Factor, Multi-Item Approach. J. Market. Manag. 1994, 10, 725-742. Available online: http:/ /www.tandfonline.com/doi/abs/10.1080/0267257X.1994.9964318 (accessed on 18 October 2016). [CrossRef]

29. Popescu, C.C.; Bostan, I.; Robu, I.B.; Maxim, A.; Maxim, L. An Analysis of the Determinants of Entrepreneurial Intentions among Students: A Romanian Case Study. Sustainability 2016, 8, 771. Available online: http:/ / www.mdpi.com/2071-1050/8/8/771 (accessed on 5 March 2017). [CrossRef]

30. Hosseininia, G.; Ramezani, A. Factors Influencing Sustainable Entrepreneurship in Small and Medium-Sized Enterprises in Iran: A Case Study of Food Industry. Sustainability 2016, 8, 1010. Available online: http: / /www.mdpi.com/2071-1050/8/10/1010 (accessed on 5 March 2017). [CrossRef]

31. Kritikos, A.S. Entrepreneurs and their impact on jobs and economic growth. IZA World Labor 2014, 8, 1-10. Available online: https:/ / wol.iza.org/uploads/articles/8/pdfs/entrepreneurs-and-their-impact-on-jobsand-economic-growth.pdf (accessed on 5 March 2017). [CrossRef]

32. Wong, P.K.; Ho, Y.P.; Autio, E. Entrepreneurship, Innovation and Economic Growth: Evidence from GEM Data. Small Bus. Econ. 2005, 24, 335-350. Available online: http://link.springer.com/article/10.1007/s11187005-2000-1 (accessed on 18 October 2016). [CrossRef]

33. Valliere, D.; Peterson, R. Entrepreneurship and economic growth: Evidence from emerging and developed countries. Entrep. Reg. Dev. 2009, 21, 459-480. Available online: http://www.tandfonline.com/doi/abs/10. 1080/08985620802332723 (accessed on 12 July 2016). [CrossRef]

34. Hessels, J.; van Stel, A. Entrepreneurship, export orientation, and economic growth. Small Bus. Econ. 2011, 37, 255-268. Available online: http://link.springer.com/article/10.1007/s11187-009-9233-3 (accessed on 5 March 2017). [CrossRef]

35. González-Pernía, J.L.; Peña-Legazkue, I.; Vendrell-Herrero, F. Innovation, entrepreneurial activity and competitiveness at a sub-national level. Small Bus. Econ. 2012, 39, 561-574. Available online: http://link. springer.com/article/10.1007/s11187-011-9330-y (accessed on 10 June 2016). [CrossRef]

36. Yoon, J.; Kim, D.S. Empirical Relationships among Technological Characteristics, Global Orientation, and Internationalisation of South Korean New Ventures. Sustainability 2016, 8, 1254. Available online: http: / /www.mdpi.com/2071-1050/8/12/1254 (accessed on 19 March 2017). [CrossRef] 
37. Li, Z.; Ding, T.; Li, J. Entrepreneurship and economic development in China: Evidence from a time-varying parameters stochastic volatility vector autoregressive model. Technol. Anal. Strateg. Manag. 2015, 27, 660-674. Available online: http:/ / www.tandfonline.com/doi/abs/10.1080/09537325.2015.1034676?journalCode= ctas20 (accessed on 17 January 2017). [CrossRef]

38. Li, H.; Yang, Z.; Yao, X.; Zhang, H.; Zhang, J. Entrepreneurship, private economy and growth: Evidence from China. China Econ. Rev. 2012, 23, 948-961. Available online: http:/ /www.sciencedirect.com/science/article/ pii/S1043951X1200051X (accessed on 26 July 2016). [CrossRef]

39. Anyadike-Danes, M.; Bjuggren, C.M.; Gottschalk, S.; Hölzl, W.; Johansson, D.; Maliranta, M.; Myrann, A. Accounting for Job Growth: Disentangling Size and Age Effects in an International Cohort Comparison; Enterprise Research Centre: Coventry: Birmingham, UK, 2013. Available online: https:/ /pdfs.semanticscholar.org/ becb/77633eaf3ed91e76ddc5f33239d97b9bc793.pdf (accessed on 19 January 2017).

40. Haltiwanger, J.C.; Jarmin, R.S.; Miranda, J. Who Creates Jobs? Small Versus Large Versus Young. Rev. Econ. Stat. 2013, 95, 347-361. Available online: http://www.mitpressjournals.org/doi/abs/10.1162/ REST_a_00288 (accessed on 05 March 2017). [CrossRef]

41. Baptista, R.; Preto, M.T. New firm formation and employment growth: Regional and business dynamics. Small Bus. Econ. 2011, 36, 419-442. Available online: http:/ /link.springer.com/article/10.1007/s11187-0099254-y (accessed on 10 June 2016). [CrossRef]

42. Kuhn, J.M.; Malchow-Møller, N.; Sørensen, A. Job creation and job types-New evidence from Danish entrepreneurs. Eur. Econ. Rev. 2016, 86, 161-187. Available online: http://www.sciencedirect.com/science/ article/pii/S0014292115001865 (accessed on 26 July 2016). [CrossRef]

43. Mandelman, F.S.; Montes-Rojas, G.V. Is Self-employment and Micro-entrepreneurship a Desired Outcome? World Dev. 2009, 37, 1914-1925. Available online: http://www.sciencedirect.com/science/article/pii/ S0305750X09000989 (accessed on 10 June 2016). [CrossRef]

44. Naudé, W. Entrepreneurship, developing countries, and development economics: New approaches and insights. Small Bus. Econ. 2010, 34, 1-12. Available online: http://link.springer.com/article/10.1007/s11187009-9198-2 (accessed on 05 March 2017). [CrossRef]

45. Congregado, E.; Golpe, A.A.; Carmona, M. Is it a good policy to promote self-employment for job creation? Evidence from Spain. J. Policy Model. 2010, 32, 828-842. Available online: http:/ /www.sciencedirect.com/ science/article/pii/S0161893810000803 (accessed on 26 July 2016). [CrossRef]

46. Niţu-Antonie, R.D.; Feder, E.S. Labour market dynamics as time-lagged effect of entrepreneurship in the case of Central and Eastern European countries. Proc. Econ. Financ. 2012, 3, 950-955. Available online: http:/ / www.sciencedirect.com/science/article/pii/S2212567112002560 (accessed on 10 December 2012). [CrossRef]

47. Fritsch, M.; Mueller, P.; Weyh, A. Direct and Indirect Effects of New Business Formation on Regional Employment. Appl. Econ. Lett. 2005, 12, 545-548. Available online: http:/ /www.tandfonline.com/doi/abs/ 10.1080/13504850500142346?journalCode=rael20 (accessed on 10 June 2016). [CrossRef]

48. Ács, Z.J.; Armington, C. Employment Growth and Entrepreneurial Activity in Cities. Reg. Stud. 2004, 38, 911-927. Available online: http:/ /www.tandfonline.com/doi/abs/10.1080/0034340042000280938 (accessed on 20 August 2016). [CrossRef]

49. Van Stel, A.; Storey, D. Link Between Firm Births and Job Creation: Is there a Upas Tree Effect? Reg. Stud. 2004, 38, 893-909. Available online: http:/ /www.tandfonline.com/doi/abs/10.1080/0034340042000280929 (accessed on 20 August 2016). [CrossRef]

50. World Economic Forum. Global Competitiveness Report. Available online: http://reports.weforum.org/ global-competitiveness-index/ (accessed on 26 October 2016).

51. GEM Consortium. Global Entrepreneurship Monitor, Global and Country Reports. Available online: http:/ / www.gemconsortium.org/report (accessed on 25 October 2016).

52. International Monetary Fund. World Economic Outlook Database. Available online: https://www.imf.org/ external/pubs/ft/weo/2016/02/weodata/index.aspx (accessed on 25 October 2016).

53. International Labour Organization. Key Indicators of the Labour Market. Available online: http://www.ilo. org/global/statistics-and-databases/research-and-databases/kilm/WCMS_422399/lang--en/index.htm (accessed on 28 August 2016).

54. Mehmetoglu, M.; Jakobsen, T.G. Applied Statistics Using Stata: A Guide for the Social Sciences; SAGE Publications: London, UK, 2016; pp. 1-350. 
55. Zu, L. International Perspective on Sustainable Entrepreneurship. In Sustainable Entrepreneurship; Weidinger, C., Fischler, F., Schmidpeter, R., Eds.; Springer: Berlin/Heidelberg, Germany, 2013; pp. 67-100.

56. Carod, J.M.A.; Solís, D.L.; Bofarull, M.M. New business formation and employment growth: Some evidence for the Spanish manufacturing industry. Small Bus. Econ. 2008, 30, 73-84. Available online: http://link. springer.com/article/10.1007/s11187-007-9051-4 (accessed on 29 August 2016). [CrossRef]

57. Santini, C. Ecopreneurship and Ecopreneurs: Limits, Trends and Characteristics. Sustainability 2017, 9, 1-12. Available online: www.mdpi.com/2071-1050/9/4/492 (accessed on 23 May 2017). [CrossRef] 